\title{
Vojne rane se celijo počasi
}

BOŽIDAR JEZERNIK

Srbski veleposlanik na Dunaju Jovan Jovanović je dunajske odgovorne kroge opozoril na nevarnosti, ki utegnejo prežati na prestolonaslednika Franca Ferdinanda med njegovim obiskom Sarajeva na Vidovdan leta 1914. Njegov obisk na prvi praznični Vidovdan po kosovski bitki in spremljajoče vojaške manevre bi namreč mogel kdo razumeti kot »izzivanje Srbov«; lahko bi se celo pripetilo, da bi se »med srbskimi vojaki sprožila kakšna puška in zadela, kogar ne bi bilo treba « (Ćorović 1936: 602). Veleposlanikovo opozorilo je naletelo na gluha ušesa, oblasti so pri organiziciji prestolonaslednikovega obiska $v$ Bosni in Hercegovini »zanemarile vsako previdnost «(Poincaré 1921: 178). Desetletja pozneje se je angleški zgodovinar Fred Singleton spraševal, ali so bili neustrezni varnostni ukrepi pravi kontrast varnostnim 
ukrepom med obiskom cesarja Franca Jožefa leta 1910 posledica $\gg$ monumentalne neučinkovitosti « avstro-ogrskih oblasti ali pa je za to dejstvo treba poiskati neko »bolj zloveščo razlago « (Singleton 1985: 115; prim. Lilek 1927: 24-8; West 1942: I, 356-59).

Nadvojvoda Franc Ferdinand je odpotoval v Bosno in Hercegovino, da je osebno poveljeval na vojnih manevrih. Po njihovem zaključku se je 28. junija v Sarajevu, okrašenem z zastavami in cvetjem, na ulicah, polnih ljudi, udeležil velike parade. Dan slovesnega zaključka manevrov je bil poseben dan. Prav tega dne se je prestolonaslednik svečano odrekel pravici do nasledstva svojih nerojenih potomcev zaradi morganatskega zakona z grofico Zofijo Chotek (West 1942: I, 351; Fraser 2014: 35). Na isti dan pa je padel tudi »praznik, ki je pozival in spominjal vsakega Srba na maščevanje proti vsem tiranom, ki so hoteli še naprej držati srbski narod razdeljen in neujedinjen v suženjstvu in temi « (Obradović 1928: 6), zato so številni parado razumeli kot »namerno izzivanje srbskih čustev « (Bartulović 1925: 45; Obradović 1928: 6; Ćorović 1936: 594). V tem kontekstu Principovi streli mnogih niso presenetili. »Našel se je Miloš, « so komentirali, »ki je ubil Murata na vidovdan.« (Obradović 1928: 7; glej tudi West 1942: I, 339-43).

Po besedah znanega avstrijskega pisatelja Alexandra Rode Rode, ki jih je prinesel berlinski Vossische Zeitung leta 1914, je Habsburška monarhija v letih od 1909 do 1912, ko bi se mogla in se morala odzvati, ostala križemrok. Po sarajevskem atentatu na nadvojvodo Franca Ferdinanda in njegovo ženo pa so vsi avstro-ogrski narodi zahtevali maščevanje za prestolonaslednika, stotine polkovnih godb je igralo Radetzky-Marsch. ${ }^{1}$ Vojna črnega orla proti belemu je bila $\mathrm{v}$ monarhiji bolj popularna od vseh predhodnih: Nemci, Slovani, Madžari in Romuni so bili iskreno ogorčeni (Nepodpisano 1914b: 18-9), oblasti pa so storile vse, da bi ta čustva čim bolj podžgale (Pavlowitch 2003: 29). Avstro-ogrsko časopisje je začelo sistematično predstavljati Srbe kot povzročitelje atentata (Lončarević 1929: 557).

V več avstro-ogrskih mestih, vključno s prestolnico, so potekale bučne protisrbske demonstracije; v Bosni, Hercegovini, na Hrvaškem in Slavoniji je prišlo celo do pogromov nad pripadniki srbskega naroda. Te izpade so spremljali ropanje srbskega premoženja, pustošenje njihovih lokalov in hiš, skrunjenje pravoslavnih cerkev. V Sarajevu in von Hötzendorf, sta bili v tistem času najpopularnejši koračnici Radetzky-Marsch in Prinz Eugen-Marsch. Prva je bila uperjena proti Italiji, medtem ko naj bi v drugi prišel do izraza $\gg$ ljudski instinkt $\ll(\gg$ Volksinstinkt $\ll)($ Conrad 1921: 170). 
mestih ob meji s Srbijo in Črno goro je bilo tudi nekaj smrtnih žrtev. Vse to se je dogajalo pod budnim očesom avstro-ogrskih policijskih in vojaških oblasti. Te so se odzvale šele tedaj, ko je že grozilo, da bo protisrbsko nasilje preraslo v splošno anarhijo, vendar niso aretirale nobenega udeleženca pogroma (Klemenčič 1914: 17; Banjanin 1915: 20-1; Anić 1919: 7; Jevtić 1923: 42-3; Paulová 1924: 4; Bartulović 1925: 45-7; Obradović 1928: 7, 17; Lončarević 1929: 557; West 1942: I, 382; Purivatra 1974: 21; Watson 2014: 57-8).

Javne pozive na maščevanje je bilo moč slišati že kmalu po atentatu, denimo, na zasedanju hrvaškega sabora, ko je poslanec Horvat rekel svojim srbskim kolegom: » Maščevali ste svojo vidovdansko državo, državo kosovske bitke. Zdaj imamo tudi mi svojo vidovdansko državo. Maščevati moramo kri svojega prestolonaslednika! « (Nepodpisano 1914d: 1-2). Vendar so bili ti pozivi sprva le sporadični in posamični. Šele konec julija 1914 je ogorčenje ljudstva »nad podlo srbsko zaroto, ki je ta zločin skovala «, nad »ničvredno srbsko državo z njeno banditsko vlado «, združeno s simpatijami do obeh žrtev atentata in občutenjem »neomajne zvestobe in udanosti « do sivolasega vladarja in avstrijske države, » butnilo iz pristne ljudske duše našega naroda na dan $\ll \mathrm{z}$ neustavljivo elementarno silo (Nepodpisano 1914m: 1).

Po oceni britanskega zgodovinarja Alexandra Watsona sta prve dni po atentatu širom Habsburškega cesarstva razpoloženje množic vodili radovednost, prevzetost nad smrtjo znane osebe (Watson 2014: 53-4). Časopisje je marljivo streglo tej radovednosti s podrobnimi poročili o potovanju posmrtnih ostankov žrtev atentata s posebnim vlakom iz Sarajeva v Metković, od tam naprej z vojno ladjo Viribus Unitis do Trsta in od tam spet naprej s posebnim vlakom prek Ljubljane, Maribora, Graza na Dunaj. Transport se je ustavljal na vseh večjih železniških postajah in $\mathrm{v}$ pristaniščih, kjer so ga pričakovale množice užaloščenih ljudi, oblitih s solzami, s prižganimi svečami v rokah (glej npr. Klemenčič 1914: 22-5).

Avstro-ogrski tisk je marljivo poročal o gnevu ljudi nad atentatorji in tistimi, ki so jih najeli in izvežbali; časopisi, ki niso trobili v isti rog, so se našli pod udarom cenzure ali so bili celo prepovedani. $\mathrm{Z}$ vseh strani je bilo slišati samó glasne zahteve, da Srbija ne sme več pošiljati bomb v Avstro-Ogrsko niti finančno podpirati časopisov in posameznih agitatorjev niti vzgajati morilcev. Nadvojvoda Franc Ferdinand je umrl, a v smrti je za sabo in svojimi cilji, kakor so jih interpretirali propagandisti, potegnil milijone. Prevoz trupel ubitega para z mesta zločina v prestolnico Cesarstva in Kraljevstva je močno vplival na razpoloženje ljudi v odnosu do Srbije; iz dneva v dan so bili nastrojeni bolj sovražno. Pisanje srbskega časopisja, ki je odgovornost 
za Principovo dejanje pripisovalo Avstro-Ogrski, in sicer zaradi njene napačne politike na Balkanskem polotoku, ${ }^{2}$ je prilivalo olje na ljudski bes, prav tako rezultati policijske preiskave, ki so nakazovali na vpletenost srbskih oblasti v sarajevski atentat (Watson 2014: 55-6).

Čeprav so večnarodno Dvojno monarhijo nekateri v mislih delili že pred začetkom vojne in najavljali njen skorajšnji padec, je atentat na prestolonaslednika in njegovo soprogo, vsaj $\mathrm{v}$ javnih proklamacijah, okrepil zavest skupne države in dinastije. Kot je pojasnjevala Ivanka Klemenčič, bi se morali Slovenci zaradi atentata še bolj zavedati, kaj jim pomeni Avstrija: odkar Slovencem vladajo Habsburžani, se je narod povzpel na tako stopnjo napredka, da jih drugi Jugoslovani občudujejo in jim zavidajo. Zato je njihova dolžnost, da ob prestolonaslednikovem grobu ponovno prisežejo zvestobo Avstriji, državi, kateri je bil Slovenec zvest več kot sedem stoletij (Klemenčič 1914: 2-3; Pečovski 1914: 135). Zlasti katoliški pisci so glasno poudarjali, da sta bila prestolonaslednik in njegova soproga dve junaški duši, za katerima neutolažljivo žaluje milijone zvestih src, da je »blagi pokojnik « z vsem duhom in vso ljubeznijo svojega plemenitega srca živel, deloval in tudi umrl » za enotno, veliko, mogočno Avstrijo, vtemeljeno na zlatem temelju katoliškega prepričanja, domovinske ljubezni, starega izročila, zvestobe in avtoritete (zakonite oblasti) «(Pečovski 1914: 130, 133). »Padla sta oba kot žrtvi katoliške avstrijske misli, « je menil Slovenčev uvodničar, $\gg$ ki je v popolnem nasprotstvu s cilji in težnjami velesrbstva « (Nepodpisano 1914c: 1).

Vendar pa sovražno stališče javnega mnenja v odnosu do Gavrila Principa ne pomeni, da so bili vsi navdušeni za kaznovanje Srbije z vojno, še zlasti ne pripadniki jugoslovanske revolucionarne mladine. Med slednjimi je bilo prisotno »mladostno pretirano « stališče, da svetlo prihodnost zagotavlja edinole nacionalna država; zanje je bil Princip junak, ki je svoje dejanje storil za uresničitev skupnih idealov. V prepričanju, da »boja ne bije svetlo orožje, temveč junakovo srce «, so računali, da junaških src, ki bi se tolkla za Avstro-Ogrsko, ni bilo prav veliko in da bo Habsburška monarhija, če bo začela vojno, »sigurno propadla «. Po njihovem sta bila možna samo dva razpleta dogajanja: ali bosta preganjanje in zatiranje narodov v nekem delu Dvojne monarhije izzvala revolucijo, ki naj bi se ji pridružili še vsi ostali narodi, in se je treba pripravljati za tak primer, ali pa bo ona napovedala vojno Srbiji, kar bo privedlo do splošne vstaje. $\mathrm{V}$ obeh primerih pa naj bi 
Avstro-Ogrska razpadla, ker bodo nastali nemiri in mobilizacije ne bo mogoče izpeljati hitro, v primeru vojne s Srbijo pa naj bi se sploh vsi vojaki slovanskih narodnosti priključili srbski vojski, ostali pa razbežali po svojih domovih, tako da do spopadov sploh ne bi prišlo (Kranjčević 1954: 16).

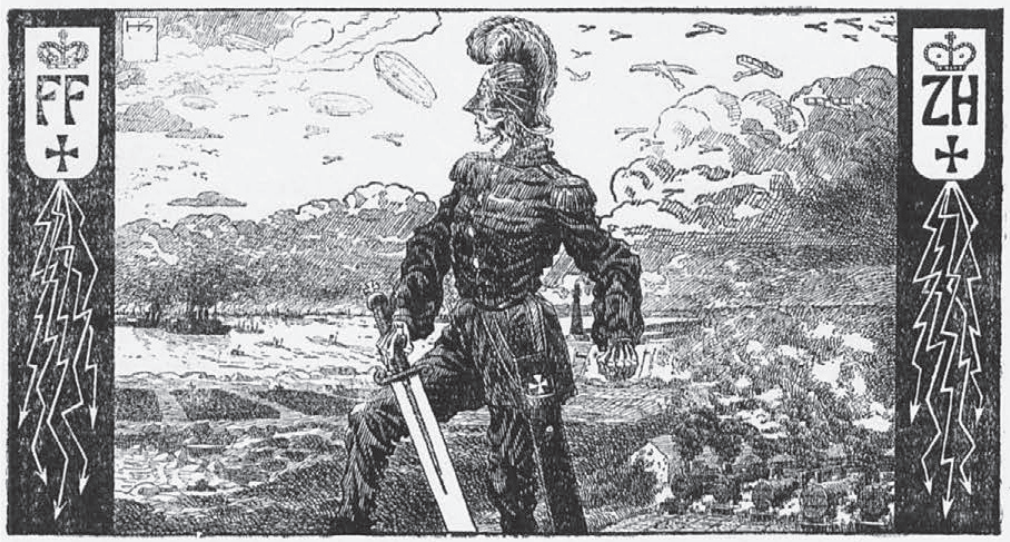

Slika 1: Ilustracija iz časopisa Svetovna Vojska, 1914, številka 1.

\section{»IMAMO VOJSKO!«}

Državljani Cesarstva in Kraljevstva so tedaj ob pomoči medijske propagande ter policijske represije in cenzure v manj kot mesecu dni poleti 1914 prehodili dolgo pot, nasičeno s čustvi, ki je kulminirala v prepričanju množic, da je treba »razčistiti « odnose s Srbijo (Watson 2014: 56). V tem procesu so sarajevski atentat in njegove žrtve odigrali vlogo katalizatorja. Po besedah tedanjih propagandistov je bila kri dveh ljubljenih oseb prelita po tleh, a iz njune prelite krvi je zrasla roža vrline. Ta roža je porodila cvet junaštva, požrtvovalnosti, edinstva, krščanske ljubezni in še mnogo drugih lepih cvetov (Nepodpisano 19140: 2). Mesec dni po sarajevskem atentatu na prestolanaslednika je Dvojna monarhija uporabila atentat kot povod za napoved vojne Kraljevini Srbiji. Vojna naj bi bila »krvavi pogreb « za obe žrtvi sarajevskega atentata:

Strašno veličasten pogreb ima Franc Ferdinand. Nad 20 milijonov oboroženih mož in fantov - cvet cele Evrope - grozo vzbujajoči pogrebci; nebo rdi od strelov, ogenj zažganih trdnjav in mest prodira 
oblake, - bliski in požari svetijo ob tem strahotnem pogrebu grom topov in pušk pretresa zemlji srce, in v divjih glasovih, ki oznanjajo strah in trepet odmeva od nebesnega oboka; - salve v pozdrav kruto umorjenemu, nepozabnemu rajniku. Za vsako njegovo kapljo krvi se jih prelijejo nešteti curki; za vsako solzo, ki jo točijo za njim mlade sirotice, - potoki solza. Cela Evropa plače! To je pogreb.

Razjarjena volja avstrijskih narodov, do srca zadeta ljubezen do vladarja in domovine kliče $k$ pogrebu $z$ vojno trombo, z žvenketanjem bridkih sabelj, s trdim, pogumnim korakom naše armade, ki se zemlja stresa pod njo in ki gre iskat pravice in zahtevat stalnega miru od sovražnika. Plah se stiska v kotu verolomni, zavratni Srb in njegov ničvredni pajdaš. $\mathrm{H}$ »krvavemu pogrebu « svojih žrtev mora in ž njima vred bo moral zakopati za vedno svoje divje sovraštvo, svoje morilne namene in svoje srbstvo, da mu ne ostane več sledi na zemlji.

(Domoljub 1914: 3)

Uspešna mobilizacija $v$ večnarodnem imperiju je bila precej bolj zapleteno podjetje kot $\mathrm{v}$ nacionalni državi. Ne le, da je bilo treba plakate z razglasom mobilizacije natisniti v petnajstih jezikih, večji problem je bila odsotnost skupne identitete. V Dvojni monarhiji je nacionalna ideologija narode bolj razdvajala, kot jih je združevala, zato je bila povezanost državljanov kot zavednih pripadnikov več narodov, od katerih so bili mnogi v konfliktnih odnosih drug z drugim, zelo rahla (Watson 2014: 90). Slovencem, ki so jih vpoklicali v vojsko proti Srbiji, na primer, Srbi iz Bosne in Hercegovine niso bili nič bližji od Srbov, proti katerim so marširali v vojni. Avstro-ogrska vojna propaganda je poskušala ustvariti sliko povezane večnarodne skupnosti, a te od pomladi narodov naprej v resničnosti ni bilo več. Državni organi so si sicer marljivo prizadevali za oblikovanje slike enotnih in povezanih narodov, a za vsakim oglom je kukala zaskrbljenost glede odnosa (jugo)slovanskega prebivalstva do vojnega pohoda črno-žoltega dvoglavega orla. Ali se bo vse bolj pomembno narodno vprašanje odražalo tudi na vojnih naporih? Zahvaljujoč splošnemu navdušenju za kaznovanje krivcev za sarajevska umora, kakor tudi cenzuri, se to vprašanje ni pogosto zastavljalo $\mathrm{v}$ javnosti (Orzoff 2004: 162).

$\mathrm{V}$ dneh, ko je bila Avstrija »prisiljena, da z mečem piše svojo zgodovino in s topovi utrjuje temelje svoje države v korist vseh njenih narodov «, so vodilne slovenske politične stranke, drugi mnenjski voditelji in časopisje enoglasno pritegnili bojeviti retoriki. Slovenec je v članku z zgovornim naslovom »Živela Avstrija! Doli s Srbijo! « poročal o velikanskem vojnem navdušenju slovenskega naroda. Rezervisti naj bi se rade volje odzivali pozivom ter prihajali v Ljubljano z vriskanjem in prepevanjem: »Zavrela je junaška kri. Vse hrepeni za tem, kaznovati cinično-hudodelsko Srbijo, to banditsko državo, ki je garja 
na telesu Evrope, sramota za kulturo današnjega veka « (Nepodpisano 1914h: 1). Slovenec ni mogel zadrževati svojih čustev:

\author{
$S$ kanoni vas pozdravimo \\ vi Srbi; \\ dom hladen vam postavimo \\ ob vrbi ... (Nepodpisano 1914g: 1)
}

$\mathrm{Na}$ Dunaju ali v Budimpešti, Pragi ali Zagrebu, Innsbrucku ali Krakovu je bila na straneh sodobnega tiska slika vojne podobna kot jajce jajcu, slika spontanega navdušenja državljanov za vojni pohod na Rusijo in Srbijo. Čete mobiliziranih vojakov so med korakanjem na železniške postaje po ulicah, prekritih s cvetjem in obdanih z množicami veselih ljudi, prepevale borbene in patriotske pesmi. Povsod je bilo videti samo navdušenje nad vojno, kot da so povsod sami privrženci boga Marsa (Herceg 1919: 13; Blašković 1939: 79; Cornwall 2000: 16). Kot je ob tej zgodovinski uri zapisal dnevnik Slovenec, so bili avstro-ogrski narodi svojemu najvišjemu vojnemu gospodu dolžni hvaležnost, »ker je sklenil velik sklep, od katerega izvedbe nas danes nič več ne zadrži «. Zaradi tega, ker Srbija ni sprejela vseh avstro-ogrskih zahtev, je namreč cesar sprejel sklep, naj namesto besed govorijo dejanja. »Zdaj veljaj le ena misel: Naprej! Cesar pričakuje, cela monarhija pričakuje, da vsak, ki gre na vojsko, stori svoje in da pridejo naši vojaki $s$ slavo nazaj v domovino « (Nepodpisano 1914k: 2). V tem duhu je bila za slovensko časopisje vojna proti Srbiji »vojska pravice nad krivico «, »boj poštenosti proti zavratnosti «, »boj civilizacije proti prostaštvu «, »boj viteštva proti nizkosti«. Če je bila kdaj kakšna vojna pravična, je zatrjeval uvodnik v Slovencu, je to vojna proti Srbiji, »tej sramotni državi, ki živi samo od umora, sleparije in verolomstva «. Ponižanje Srbije naj bi bila edina pot do »resničnega, trajnega miru «, a takega miru nikdar ne bo, »če bi Evropa na sebi trpela banditsko srbsko gnezdo (Nepodpisano 1914h: 1).

Napoved vojne Srbiji in splošno mobilizacijo so mesta širom Dvojne monarhije pospremila $z$ organizacijo velikih javnih manifestacij, časopisje pa je v skladu z uradnimi navodili, kako poročati, vojni pohod pozdravljalo $\mathrm{v}$ številnih bombastičnih uvodnikih (Romsics 2006: 27; Bobič 2012: 29). Povzdigovali so »krasni značaj« prestolonaslednika, izbornega družinskega očeta in soproga, ter poudarjali, $s$ kakšnim navdušenjem in veseljem ga je v Sarajevu sprejelo »pošteno « prebivalstvo, medtem ko so Srbi pripravili za sprejem bombe in revolverje. Da ni mogoče zatajiti, da grozni zločin ni bil dejanje posameznika, temveč so ga pripravili v Beogradu; zato je zanj odgovorna srbska država. Atentatorji niso hoteli zadeti le prestolonaslednika in njegove 
soproge, ampak predvsem »veliko našo Avstrijo «. V Srbiji, kot so pojasnjevali, je rastlo sovraštvo zoper Avstrijo, odkar je ta anektirala Bosno in Hercegovino. Srbija se je v balkanskih vojnah razširila na račun drugih zmagovitih držav proti jugu, zdaj se hoče razširiti še proti severu. Ker pa je Avstro-Ogrska branila » pošteno pridobljeno svojo last «, jo hoče Srbija premagati z revolucijo in umorom. Na tem izhodišču so mobilizacijo vojakov opisovali kot vesel dogodek, na katerega se je na tisoče in tisoče slovenskih fantov in mož menda odzvalo nadvse odločno $\gg z$ blagoslovom nebes in celega naroda « (Nepodpisano 1914n: 1). $Z$ velikim veseljem so se javljali v vojašnice in od tam na bojno polje. Ko so z vlaki odhajali na jug, je bilo slišati veselo prepevanje bojnih in domoljubnih pesmi. Sliši se le en klic: »Ko bi le že skoraj mogli udariti nad Srba! $\ll^{\mathbf{3}}$ (Nepodpisano 1914i: 1).

Časopisne strani so bile tako na gosto napolnjene $s$ hujskaškim jezikom, da ni bilo nobenega prostora za malodušje. Nasprotno, poročila o mobilizaciji so navajala, da so odhajanje vojakov na vojna prizorišča celo njihovi najbližji pospremili z junaško držo: »Oče vojak-junak; kaj naj bo drugačna žena, drugačni njegovi otroci? - Sin vojak-junak; kaj naj ne bo takšna njegova mati, ki ga je rodila in vzgojila? « (Flerè 1916: 34). Tedenske slike so navduševale svoje bralce, med drugim, tudi $s$ pesmijo o Kranjskem Janezu, ki se je izmed vseh avstrijskih vojakov najbolj odlikoval po svojem junaštvu: »Narodi avstrijski / na migljaj cesarja / kot en mož borijo / se za dom, vladarja. / Slednji polk med sabo / v hrabrosti tekmuje, / izmed vseh se »kranjski / Janez « odlikuje. / Kjer šrapnelov, krogel / dež se gosti vsuje, / kjer nevihta bojna / zadivja najhuje, / tja hitijo Kranjci / na usodno mesto, / kot nevstrašni levi / se borijo zvesto. / Njih železna roka / preje ne omaga, / dokler $\mathrm{v}$ tla ne stare / ljutega sovraga. / Je in bo slovelo / kot slovi še danes: / »Prvi med junaki / je naš kranjski Janez!« (M. K. 1915: 2).

Manifestacije ljudskega ogorčenja zoper sarajevske atentatorje so potekale v številnih mestih Cesarstva in Kraljestva, medtem pa je Ljubljana še vedno molčala. V stolnem mestu vojvodine Kranjske je po poročanju iz posebne izdaje Slovenca »ponavljala prisego stare svoje zvestobe državi « šele tistega dne, ko je Avstro-Ogrska napovedala vojno Srbiji. Manifestacija prekipevajočih čustev je presegla vse množične tistim med njimi, » ki so se zgrudili, brezplodno izkrvaveli, ki trohne v neblagoslovljeni zemlji, pozabljeni, neslavni ...«, spominjal dneva mobilizacije povsem drugače. Po njegovem opisu so ljudje hiteli po cestah »nemirni, bledi, objokani, prestrašeni, obupani $\ll$ in si govorili, naj Avstrijo »rajši vzame vrage « in vse tiste, ki pojdejo nad »brate《 Srbe (Matičič 1922: 3). 
manifestacije, kar jih je pomnila zgodovina mesta: na njej se je zbralo »gotovo 40.000 ljudi«. Mestne ulice so bile razsvetljene, Grad je bil bajno razsvetljen, gospodične so z mnogih oken metale cvetje na sprevod vojakov in častnikov, hiše so krasile slovenske trobojke in črno-rumene cesarske zastave (Nepodpisano 1914j: 1). Ko je spregovorilo slovensko glavno mesto, so vojni hujskači znova oživeli govor starega jezika avstrijskega patriotizma. »Živela Avstrija! « med Slovenci ni bil popularen vzklik, še zlasti po letu 1908. Zdaj je donel z vseh strani, po vseh ulicah se je orilo: »Doli s Srbijom! Fej! Doli s Srbijo! Fej Srbija! « (Nepodpisano 1914m: 1). Tedanji kranjski deželni glavar Ivan Šušteršič se je po koncu vojne spominjal, da je bila taka takrat »ljubljanska mentalnost «. Nikjer v javnosti ni bilo čutiti nestrinjanja, le nekaj dijakov je menda razširjalo po Ljubljani nekaj listkov v smislu: »Doli z vojno. Doli s klerikalci. Smrt Šušteršiču « (Šušteršič 1922: 109).

$\mathrm{Na} \gg$ globokoresni, veličastni manifestaciji $\ll \mathrm{v}$ spomin na nadvojvodo Franca Ferdinanda, ki jo je 5. julija 1914 v Ljubljani pripravila Slovenska ljudska stranka, je tedanji deželni glavar Ivan Šusteršič v imenu slovenskega vojaka cesarju izrekal » moško zvestobo «:

\footnotetext{
Ta zvestoba mu ni nikdar manjkala, naši regimenti pred sovražnikom še nikdar niso ušli, in kader bo naš cesar nas klical, da obračunimo $s$ hudodelci, ki so zakrivili serajevsko katastrofo, takrat bodo ti takozvani »bratje Srbi«, ki spominjajo na tiste janičarje, ki so svojčas klali svoje brate in dejali »Ne boj se, brate! « (Veselost), takrat bodo ti »bratje « čutili našo pest (Živahno pritrjevanje), takrat bo težka pest slovenskega vojaka, slovenskega fanta razdrobila črepinjo tistega Srba, v katerem živi požrešna megalomanija, ki ni zadovoljna s tem, kar mu je Bog dal, ampak ki bi rad ugrabil in hoče požreti vse, kakor požrešni otroki, ki nikdar ne vedo, kedaj imajo zadosti. (Klici: »Tako je!«, »Proč s Srbijo!«) (Nepodpisano 1914d: 2)
}

Ob iznenadni in velikanski spremembi so se nekateri sicer začudeno spraševali: »Ljubljana, Ljubljana, kako govore danes tvoje ulice?! Ob plapolanju svoje slovanske trobojnice kličeš pogin na slovanskega brata?! « A svojega začudenja niso delili z drugimi (Lah 1925: 100-1). A čeprav so uradni propagandisti želeli, da bi ljubljanske ulice govorile v imenu vsega slovenskega naroda jezik bojaželjnosti, gromoglasno proslavljanje napovedi vojne vendarle ni zajelo vseh. Sicer katoliški duhovnik Ignacij Breitenberger ne bi čutil potrebe, da je pripadnike katoliškega telovadnega društva Orel javno opozarjal, da so bili med Slovenci še vedno »ljudje brez srca, katerim zločinski umor ni povzročil posebne žalosti «, ter jih odvračal od branja liberalnega in socialdemokratskega časopisja, ki je po njegovi oceni med Slovenci razširjalo »ideje in misli, ki niso niti katoliške niti avstrijske! (Breitenberger 1914: 90). 
Vrhunec ljubljanske manifestacije $\mathrm{v}$ podporo vojni je potekal pred iluminiranim deželnim dvorcem. Na balkonu je stal okrašen kip cesarja Franca Jožefa I., nad njim so električne žarnice razsvetljevale začetne črke njegovega imena: F. J. I. Velika množica ljudi pred dvorcem je pozdravljala vojake z gromoglasnimi vzkliki. Z balkona jih je nagovoril Marko Natlačen: »Imamo vojsko! « Že sedmo leto, je govoril, naš sosed na jugovzhodni meji grozi in rožlja s sabljo. Kot ogromen lev je Avstrija gledala na malo nagajivo miško. Toda med tem njenim viteškim vedenjem je pritlikavi sosed postal močnejši, tako da se je velika Avstrija znašla v resni nevarnosti, da ji odtrga lep del njenega ozemlja. Hudodelski umor v Sarajevu pa je na velesrbsko idejo vrgel pravo luč, ki je mahoma prikazala vso resnost in nevarnost položaja. Da bi zaščitila svojo zakonito posest in svojemu ljudstvu zagotovila mir, Avstrija ni imela izbire: morala je poseči po orožju. Poslušalci so Natlačenov govor spremljali z »domoljubnimi klici«, kot so »Proč s Srbijo! Živela vojska! Živela Avstrija! «, tudi ko je napovedal »velike in težke žrtve «. Slovenska prihodnost, je govoril Natlačen, je »edinole v Avstriji, v mnogonarodni velevlasti mogoča «, zato bo slovenski narod tudi v tej težki uri ostal zvest svojemu cesarju in Avstriji ter vnovič dokazal, da je prav govoril Koseski, ko je rekel: »Hrib se omaje in hrast - zvestoba Slovenca ne mine. - Živela Avstrija! (Nepodpisano 1914j: 1-2).

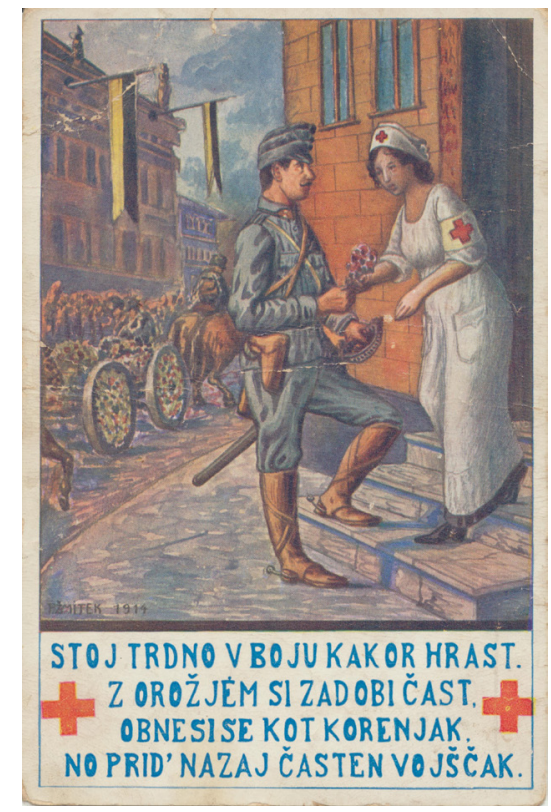

Slika 2: Stoj trdno v boju kakor hrast ..., naslikal Žmitek, 1914, Založilo deželno in gospejno društvo Rdečega križa za Kranjsko (iz zbirke avtorja). 
Ljubljanski župan in vodja tako imenovane liberalne stranke Ivan Tavčar ter ljubljanski knezoškof Anton Jeglič sta v številnih besednih vojnah pred Veliko vojno pogosto stala vsak na svojem bregu okopov v aktualnih polemikah, na veliki vojni manifestaciji pa sta oba govorila isti bojeviti protisrbski jezik. Sarajevski atentat je stališča nekdanjih nasprotnikov močno zbližal. Na patriotski manifestaciji v Ljubljani, 28. julija 1914, je župan Tavčar z mestne hiše opomnil zbrane vojake, da jim vsak kamen te starodavne hiše glasno govori, da bi slovenski narod že zdavnaj » razpadel v nič «, če ga ne bi pod svoje varstvo vzela »preslavna habsburška dinastija «. Grom topov, je župan Tavčar nagovarjal vojake, oznanja celemu svetu, da hočejo Slovenci ostati zvesti Avstrijskemu cesarstvu vse $\gg$ do konca dni $\ll$; kdor bi to hotel spremeniti, je slovenski sovražnik:

Slovenski fantje, ko se postavljate v vrste pod vojna svoja bandera, ne pozabite, da so se pod temi banderi že zbirali vaši očetje in vaših očetov očetje! Nikdar nismo doživeli, da bi se slovensko junaško srce ponosno ne dvigalo pod črno-rumeno cesarsko zastavo! Slovenska pest ni prej odnehala, da ni bil sovražnik poteptan v prah in da je ponosno vihral črnožolti prapor nad razbitimi četami onemoglega sovražnika! Tako bo tudi sedaj, ker ste vredni sinovi svojih očetov! (Nepodpisano 1914j: 2)

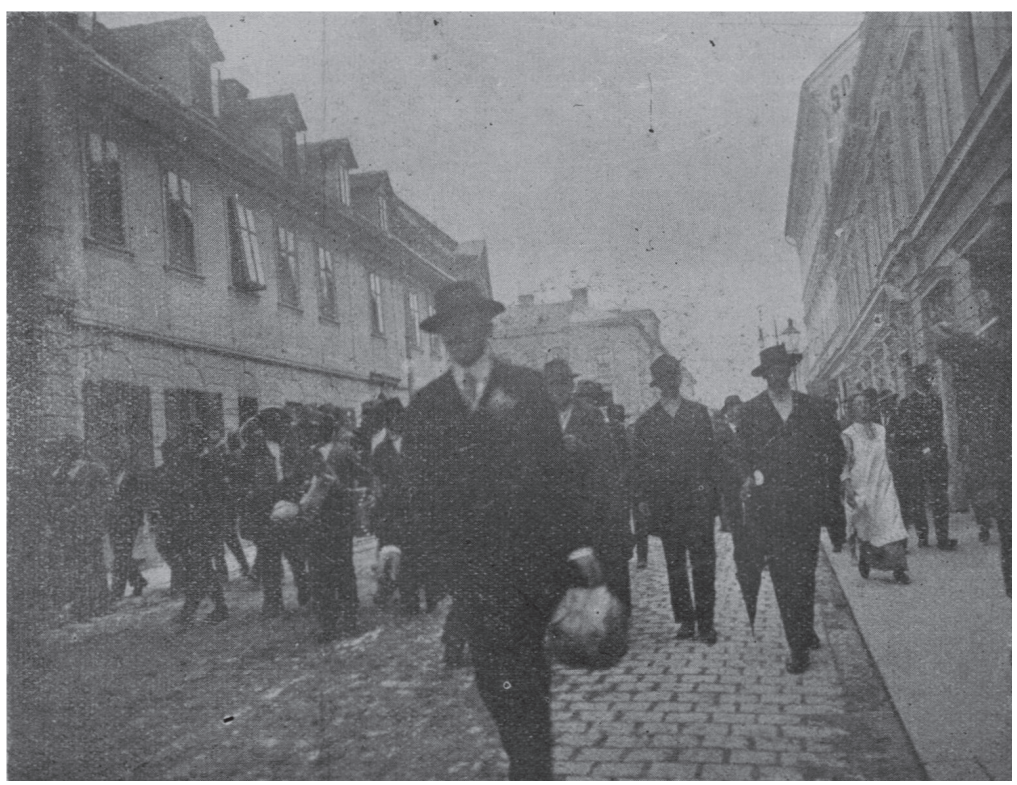

Slika 3: Mobilizacija v Ljubljani: Gorenjski fantje prihajajo s harmonikarjem po Dunajski cesti k mobilizaciji.

Škof Anton Jeglič je na začetku avgusta 1914 v nedeljski maši na dvorišču domobranske vojašnice nagovoril brambovce, preden so 
podali prisego. V nagovoru jih je škof opozoril, da odhajajo $\mathrm{v}$ pravično vojno, $\mathrm{v}$ kateri bodo $\mathrm{z}$ orožjem $\mathrm{v}$ roki kaznovali hudodelce, maščevali napeljevanje k izdajstvu ter branili katoliško Avstrijo in katoliško dinastijo. Ob tem jih je vnemal, naj se ne boje ne za družine, ne težav in tudi ne junaške, mučeniške smrti (Jeglič 1914a: 84; glej tudi 1914b: 1).

Koliko je bilo v takih besedah iskrenega čustvovanja in koliko politikantske računice, je danes težko presoditi. V Habsburški monarhiji je vojna dala vodilnim politikom širom prostrane države priložnost, da javno izrazijo svojo lojalnost cesarstvu in dinastiji. »Vojska je vojska «, je Ivan Tavčar, na primer, 5. avgusta 1914 posvaril Ivana Hribarja, »zato je treba previdnosti, zakaj ob takem času je semtertje nevarna že kaka fraza, za katero bi se v normalnih razmerah nikdo ne zmenil. Zato bom jaz na primer igral takšno hinavščino, da se bo svet čudil « (Hribar 1928: II, 110). Vdanostnih izjav cesarstvu in dinastiji, potemtakem, ne moremo razumeti zgolj kot izraze slepe pokornosti višjim oblastem, saj so jih dajali na podlagi zamolčane računice o tem, da jih bo vladar zanje nagradil z izkazi naklonjenosti po koncu vojne. Je pa nenehno izjavljanje zvestobe in vdanosti cesarju in kralju ustvarjalo ozračje cesarjeve nedotakljivosti, kar je hitro preraslo v običaj, po katerem je bilo tako izjavljanje obvezen del vsakega javnega govora. Tako je, na primer, to metodo uporabil tudi projugoslovanski in prosrbski časopis Dan (glej npr. Nepodpisano 1914f: 1). Dejstvo, da so govorniki nagovarjali javnost na tak način, po mnenju zgodovinarja Aviela Roshwalda, samo po sebi dovolj zgovorno kaže na predmoderno raven politične kulture v Habsburškem cesarstvu, hkrati pa tudi (potencialni) manko kohezivnosti (Roshwald 2001: 71).

\section{VSTAJENJE OGORČENEGA JUNAKA}

Mesec dni po sarajevskem atentatu je Habsburška monarhija napovedala vojno Kraljevini Srbiji. Vodilni možje v Kraljevini Srbiji so vedeli, kaj jih čaka, zato je srbska vlada 25 . julija 1914 objavila splošno mobilizacijo (Ristanović 1989: 11). Na avstro-ogrsko napoved vojne Srbiji se je kot prva, 31. julija, odzvala Rusija z objavo splošne mobilizacije. Rusko mobilizacijo je Nemčija uporabila kot izgovor za napoved vojne Rusiji, 1. avgusta, in ruski zaveznici Franciji dva dni pozneje. Zaradi nemškega napada na Belgijo, 2. avgusta, in Francijo, 3. avgusta, je v vojno stopila tudi Britanija, 4. avgusta, naslednjega dne, 5. avgusta pa še Črna gora. Sledila je Turčija, ki je 1. novembra, vstopila v vojno na strani centralnih sil. Leta 1915 je Italija vstopila v 
vojno na strani antante in Bolgarija na strani centralnih sil. Končno je Romunija, ko so ji obljubili Transilvanijo, stopila na stran antante 1916. leta.

Prizori po vseh evropskih mestih, od Dunaja do Berlina, od Londona do Petrograda, so bili podobni, le da so na Dunaju vzklikali »Živela Avstrija! Dol s Srbijo!«, v Petrogradu pa »Živela Srbija! Dol z Avstrijo! « (Vukićević 1924: 102). Množice na ulicah so se prepustile čustvom, ljudje so se objemali in prepevali patriotske pesmi, vihrale so zastave. Vsepovsod so odmevali emocionalni izrazi patriotizma. $\mathrm{Na}$ Dunaju, na primer, je neki študent pred spomenikom admiralu Tegetthoffu, zmagovalcu nad italijansko floto pri Visu leta 1866, nagovarjal ogorčeno množico: »Naj nas napolni junaški duh tega velikana! « (Ludwig 1915: 33). Cerkveni dostojanstveniki so blagoslavjali vojake pred odhodom na bojišče. Zelo vidno vlogo v dvigovanju patriotskega duha so odigrale ženske; na številnih kolodvorih so čakale na vagone z vojaki s cvetjem, cigareti, kavo in sladkarijami (Ludwig 1915: 32). Raznorazni stihotvorci so močnim čustvom dajali duška s sestavljanjem bolj ali manj borbenih koračnic, kot je tudi ta:

\footnotetext{
Oj, hrvatski hrabri sine

Prevezi me preko Drine,

Osvećena krv još nije,

Ferdinanda i Sofije ...
}

Njim so z druge strani Save odgovarjali na podoben način:

\author{
Petnaestog juna na Vidovdan \\ Poginuo švapski Ferdinand. \\ Srpska ga je ruka ubilaaa \\ Srpska ga je puška smaknulaaaa! (Horvat 1967: 151)
}

Avstro-ogrski propagandni stroj je prikazoval cesarja kot poosebljenje države. »Države ne moremo narisati, ne izklesati iz kamna, ne videti, ne slišati $[\ldots]$, , je razlagal vojni poročevalec profesor Rudolf Peerz, » ona je beseda, iz katere je vse, kar nas hrani, za kar torej skrbimo in delamo. Edino, kar nam jo dela vidno, to je cesar. $V$ cesarju je vtelešena država «(Peerz 1917: 14). Zvestoba » prejasnemu cesarju « naj bi imela globljo vsebino in pomen, saj naj bi bila hkrati tudi izraz in dokaz domoljubja (Peerz 1917: 3). Zato, so pozivali propagandisti, je treba v vojnem času navdse ljubljenemu sivolasemu monarhu, knezu miru in $\gg$ očetu avstrijsko-ogrskih narodov « (Holeček 1915: 2), polagati na oltar vitam et sanguinem (življenje in kri) (Nepodpisano 1915d: 1).

Vojni kurati, pastorji in imami so svoje črede v vojaških uniformah poučevali, da je zaprisega, dana cesarju in kralju, svetinja, da je dano 
besedo treba držati in se veselega srca žrtvovati zanj (glej npr. Hafner 1914: 7-8; 1915: 4; Palir 1914: 150; Limbarski 1914: 181; G. P. 1915: 89; Pečovski 1915: 93; Holeček 1915: 4; Šegula 1917: 27; Horvat 1967: 157). Cerkveni krogi so vojakom naročali »Bodi junak! « Pri čemer je biti junak pomenilo biti pripravljen na vsakovrstna pomanjkanja in težave kot nekaj, kar je v vojaškem življenju neizbežno, dalje možato in pogumno izvrševati vojaške dolžnosti in pripravljenost, da »vsak trenutek « za svojega vladarja in domovino žrtvujejo kri in življenje (Hafner 1914: 156). Uradna propaganda je ljudi prepričevala, da se je zaradi sarajevskega atentata dvignil ogorčeni junak, poln življenja in orjaške moči, raztrgal okove in vstal kakor gora, ter napovedovala, da bo kakor blisk in strela »podrl sovražnike in zmlel v prah svoje rablje « (Nepodpisano 1914l: 1). Po uradnih sporočilih so se po vojni napovedi Srbiji vsi državljani Dvojne monarhije postrojili »kot en mož« ob boku svojega cesarja in kralja ter njegove slavne vojske. Ne Slovenci ne Hrvati, čeprav po jeziku in poreklu blizki srbskemu narodu, $\mathrm{v}$ tem pogledu niso bili nobena izjema. Često in glasno je bilo mogoče slišati, kako tisti, ki žali Avstro-Ogrsko, žali tudi njih, zato tudi, bojda, niti za trenutek niso podvomili v svojo dolžnost (Nepodpisano 1914d: 4).

Najtežji napori, najgroznejše nevarnosti so mu otroška igrača, ker je
še težjih in hujših pričakoval; želi si le še bolj ugodnih prilik, da izkaže
svoje hladnokrvno junaštvo. V dežju krogel ostane miren kakor kip,
pa se po nepotrebnem ne izpostavlja; pri navalu, jurišu, se zdi, da ga je
sam ogenj in kri, tako drvi brez najmanjšega pomisleka v žrelo smrti,
pri umikanju pa je kakor železen stroj, ki dela natančno in vse in samo
to, kar mu roka poveljnika veleva. Za svoje življenje se ne briga več
kakor za stvar, obsojeno v smrt; za domovino se žrtvuje, kakor bi jo
imel rešiti sam: to je junak! Bodi tudi ti tak! (Hafner 1914: 158)

Poročila z vojnih položajev so služila dvigovanju vojne morale državljanov Dvojne monarhije, med katerimi so slovanski narodi tvorili celo večino prebivalstva. Vojni propagandisti so stanje na bojiščih upodabljali s črno-belo tehniko in na vseh straneh bojne črte opisovali »naše junake «, kako se hrabro borijo proti »srbskim divjakom «. Tako so v poročilih slovenskega časopisja slovenski in hrvaški vojaki nastopali kot junaki, ki tudi v najtežjih bitkah naskakujejo sovražnikove položaje s šalo in smehom, iz bojev pa se umikajo le neradi in na ponovno povelje (Nepodpisano 1914t: 42-3). Konec avgusta 1914 je Slovenec prinesel članek, v katerem primerja junaštvo jugoslovanskih vojakov v avstro-ogrski vojski in njihovih srbskih nasprotnikov. Čeprav je avstro-ogrsko vojno poveljstvo izrecno priznavalo, da so se Srbi borili »z veliko hrabrostjo «, je bila po zatrjevanju avtorja članka hrabrost avstro-ogrskih vojakov »še večja «. $S$ svojim junaštvom so v 
prvi vrsti stali Hrvati: »En Hrvat za tri Srbe «, je sklenil avtor članka, $\gg$ to je dosedanji nauk avstro-srbske vojske « (Nepodpisano 1914q: 1).

Črno-belo propagandno poročanje z južnega bojišča in prikazovanje »naših Jugoslovanov « kot resničnih junakov (Kosi 1914: 22), ki so se odlikovali s svojim junaštvom v bojih s Srbi, naj bi dokazovalo, da avstrijsko junaštvo še ni izumrlo in pokazalo svetu, da je srbsko visoko mnenje o svojih vojaških vrlinah zgolj puhla domišljija. Tako je, na primer, četrta številka tednika Tedenske slike, namenjenega temu, da bi slovenski bralci mogli spremljati potek vojne, prinesla podroben opis bojev avstro-ogrskih čet na zahodu Srbije. V teh bojih s Srbi so se slovenski vojaki menda odlikovali s »posebnim junaštvom «, zlasti 16 , 53. in 79. pešpolk, v katerih so bili častno zastopani kajkavci iz Zagorja (»s svojim kajkavskim narečjem so itak po krvi in naravi Slovenci ter le po svoji državni pripadnosti Hrvati«) in »pravi Slovenci« (Nepodpisano 1914r: 3-4). »Pa, saj je bilo že od nekdaj tako «, je dodajal uradni propagandist iz središča cesarstva, »kjer se je do zdaj še bojeval slovenski vojak za svojo domovino, vselej se je bojeval kot junak od pêt do glave in tak tudi ostane « (Peerz 1916a: 3).

Poleg tega, da so $s$ takim črno-belim prikazovanjem bojevanja »naših junakov « proti »srbskim divjakom « dvigovali vojno moralo jugoslovanskih vojakov v avstro-ogrskih uniformah, so med njimi in njihovimi nasprotniki gradili vse višji zid divide et impera. Da vojna resničnost ni bila tako jasno izniansirana na belo in črno stran, ampak je bilo v njej polno drugih barv, največ krvavordeče, najbolje pokaže dogodek iz cerske bitke sredi avgusta 1914. Pripadniki 28. praškega polka se niso hoteli boriti proti svojim slovanskim bratom. Na ukaz, naj jurišajo na srbske položaje, so njegovi pripadniki raje odvrgli orožje in se podali proti srbskim položajem glasno pojoč »Hej, Slovani! «. Njihova usoda je bila tragična: nihče ni preživel. Nejasno je ostalo le, ali zaradi srbskih strelov ali strelov avstro-ogrskih oficirjev, ki so streljali nanje kot na dezerterje (Bálek 2018: 23). Na drugi strani pa niti v bojnih vrstah zoperstavljenih vojska niso bili izključno državljani ene ali druge države. Tako je padel kot ena prvih slovenskih žrtev vélike vojne v Srbiji, v noči s 16. na 17. avgust 1914 pod Cerom kot jugoslovanski dobrovoljec v srbski vojski, eden vodilnih preporodovcev, kladivar Anton Jenko, » mladi vitez iz vojske Kralja Matjaža « (Kolar 1930: 5; Paulin 1936: 135; Ristanović 1989: 60). Medtem ko je v bolnišnici ležal Jenkov tovariš Vladislav Fabjančič, mu je Niko Županič pisal, da ga je težko prizadela smrt mladega Jenka: »Žal mi je za Jenka, ki je bil lep kot deklica in mlad kot kaplja rose, a je moral umreti.« In dodal: »A sem ponosen na to, da je tudi slovenska kri orosila bregove Cera « (cit. Ristanović 1989: 64). 
Beograjska Politika je 1. avgusta 1914 objavila članek o $\gg$ uporabi « južnih Slovanov v vojni proti Srbiji. Po navedbah avtorja članka je Avstro-Ogrska grozila Srbiji, da jo bo tepla s svojimi slovanskimi polki, zbranimi v osmih korpusih (vsak po 60.000 vojakov nominalno). Kot piše člankar, je bila avstro-ogrska računica taka: »Če naši slovanski polki potolčejo Srbijo, potem nimamo za kaj skrbeti. Če pa bo Srbija potolkla njih, potem bo med temi potolčenimi Slovani ostalo strašno sovraštvo do Srbije « (Nepodpisano 1914p: 1). A resnično življenje na bojiščih se ni vedno in povsem ravnalo v skladu z željami gospodarjev vojne. Poročnik 28. osiješkega polka Marko Jakovljević, sicer Srb iz Vojvodine, je konec petega tedna vojne celo sklenil dvourno premirje s sovražnikom. Njegovi vojaki, Srbi in Šokci iz Srema ter Srbijanci, so se objemali in poljubljali. Ko je avstrijska artilerija začela streljati v njihovi bližini, so se ločili z vzklikanjem: »Živeli Srbi in Hrvati! « (Jakovljević 1923: 5; glej tudi Wendel 1925: 741-42)

Slovanske vojake, »te hrvaške in srbske svinje «, so pogosto pošiljali v prve bojne vrste, da bi se »poklali s Srbi « (Banjanin 1915: 14; Potočnjak 1915: 6; Anić 1919: 6; Supilo 1970: 474). A ko so v bojih pri Šabcu in Valjevu hrvaški vojaki, misleč, da se bojujejo zase, razvili hrvaško zastavo, so jo Madžari vrgli na tla in »gnusno oskrunili« (Potočnjak 1915: 6). Na srbski fronti so v prve bojne vrste pošiljali tudi prečanske Srbe, da bi se bojevali v avstro-ogrski uniformi proti »svojim bratom « (Obradović 1928: 8). Po nekaterih podatkih je bil med mobiliziranimi v Bosni in Hercegovini velik odstotek Srbov. Ali želijo na bojno črto, jih je od tisoč vprašanih Srbov izjavilo »samo 18, da želijo oditi na drugo bojišče « (Blašković 1939: 81). Kot je v tekstu, objavljenem v Nišu, leta 1915 opozarjal Jovan Banjanin, predvojni srbski politik iz Hrvaške in član Jugoslovanskega odbora, je med Srbi v Dvojni monarhiji živel še precejšen del generacije, med katero je bila najbolj popularna pesem $\gg$ Rado ide Srbin u vojnike «, z znanim refrenom: »Kad zaželi svetli car, u smrt skače graničar « (Banjanin 1915: 18).

Po vojni je bila ta plat zgodbe o véliki vojni deležna posebne obravnave. Pravoslavni vojni svečenik v avstro-ogrski vojski Dušan Obradović se je v svoji knjigi, objavljeni deset let po koncu vojne, spominjal, da so prečanske Srbe pošiljali v prve bojne vrste, da so se borili proti »svojim bratom «(Obradović 1928: 8). Na samem bojišču so menda številni med njimi pomislili, da bi bilo morda bolje, če patriarh Čarnojević svoje črede ne bi odvedel v te kraje in bi ostali vsi skupaj. In če bi se morali bojevati, bi se bojevali kot složni bratje, kot dostojni potomci Miloša Obilića in Marka Kraljevića. »Ampak da Miloš vstane na Marka?! Marko pa na Miloša, Srb na Srba, brat na 
brata. Ali obstajata večja žalost in tragika pri enem narodu? « (Obradović 1928: 19)

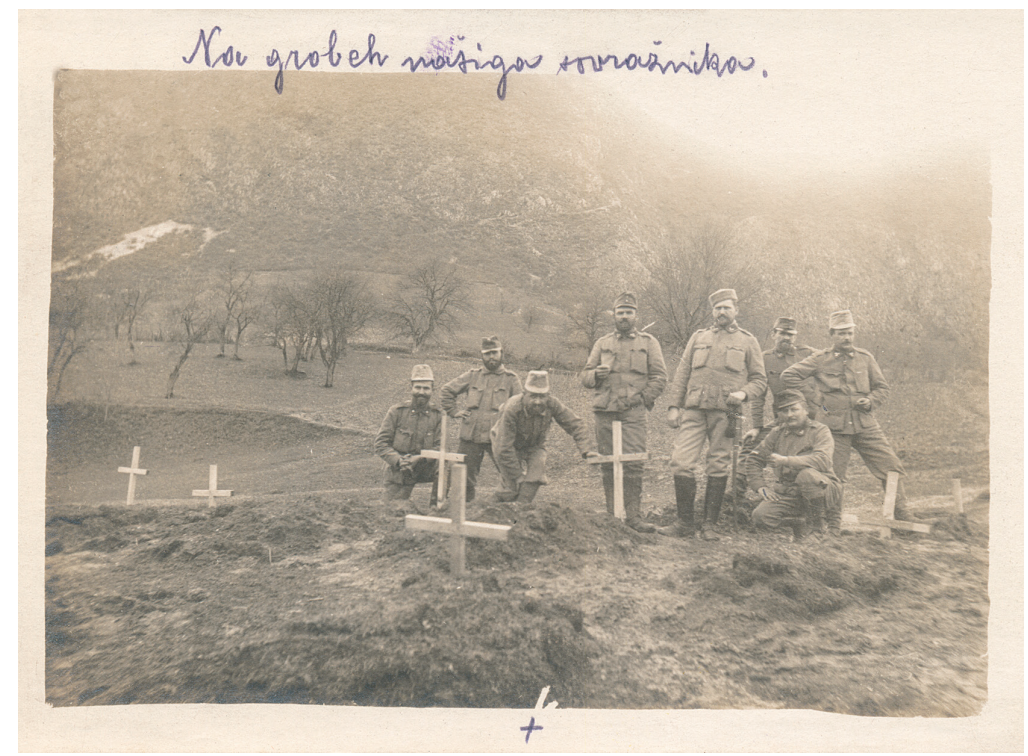

Slika 4: Fotorazglednica, poslana duhovniku in zgodovinarju Ivanu Vrhovniku v začetku leta 1915 iz zahodne Srbije. Pošiljatelj se je označil s križcem (iz zbirke Milana Škrabca).

\section{BELA RESNICA, ČRNA LAŽ}

Slovenski tisk je začetek vojne prikazoval na prav pravljičen način. Cesar je zaupal v pravičnost svoje stvari, $v$ svojo hrabro vojsko in svoje zveste narode - in ni se motil. Ko jih je vpoklical v vojsko, so vsi prihiteli k njemu »kakor otroci k svojemu očetu «. Pozabili so na medsebojne prepire in se združili v eni sami misli: rešiti domovino in zapisati v kri pravico, ki jo je terjal njihov cesar. Med številnimi narodi, ki so na cesarjev poziv pohiteli branit domovino, je bil tudi »naš mali, svetu do sedaj skoro nepoznani narod slovenski «. Na bojišče so šli ukajoč:

Mi čvrsti Slovenci smo,

gremo na boj

za pravdo, za dom, za

cesarja! (Nepodpisano 1915e: 2)

Avstro-ogrski tisk je poročal o poteku vojne in zunanji politiki, pri čemer je v skladu s policijskimi odredbami bolj ali manj iskreno 
navduševal svoje številno bralstvo ${ }^{4}$ za patriotsko požrtvovalnost (Erjavec 1928: 263). Tako je bilo v dnevniku Slovenec iz pisem slovenskih vojakov mogoče prebrati, kako se slovenski vojaki junaško in zmagovito borijo na vseh bojiščih. Nekdanji član slovenskega gledališča $\mathrm{v}$ Ljubljani Josip Molek, ki je bil desetnik, je Slovencu pošiljal tisoč pozdravov z južnega bojišča in se pohvalil, češ da »Srbi beže, da jih komaj dohajamo « (Nepodpisano 1914u: 1). V isti številki Slovenca je bilo mogoče prebrati tudi to, da je skupina ranjenih vojakov Ivanu Šušteršiču in njegovi soprogi poslala razglednico $s$ pozdravom in pripisom: »Hrast se omaje in hrib, zvestoba Slovencev ne gane! Ura! «

Cenzura je skrbno pazila, da je bila vsebina čaopisja v skladu z uradno politiko. Nekatere časopise je oblast prepovedala, na primer, Slovenski Branik in Slovenski ilustrirani tednik (Erjavec 1928: 221), spet drugi, na primer prosrbski Dan, so položili svoj dar na oltar jugoslovanske misli in utihnili (Lah 1925: 97). Cenzura je zaplenila ne le tisto, kar je bilo napisanega, temveč tudi neizrečene misli. Oskar Tartaglia je to pokazal v izdaji Zastave z dne 13. julija 1914. Objavil je uvodnik z naslovom Kako se sadi kupus (»Tema o kojoj je dozvoljeno pisati«), poleg njega pa članek Sloboda śtampe (»Tema o kojoj je zabranjeno pisati i zato uredništvo zaplijenilo «) (Tartaglia 1928: 78-9).

Odkrito pisanje v nasprotju $\mathrm{z}$ uradnimi stališči ni bilo mogoče, zlasti ne v prvih dveh vojnih letih. Vendar to ne pomeni, da se cenzorskim škarjam niso izmaknila nekatera skrbno izbrana sporočila. Toliko laže, kolikor bolj so bili bralci vešči branja »med vrsticami« (Hribar 1929: 195). Dokaj zgovorna so bila že prazna mesta na časopisnih straneh, posledica cenzorskih posegov, brez katerih ni bilo niti poudarjeno proavstrijsko glasilo organizacije slovenskih Orlov (glej npr. številko iz decembra 1914. leta). Po spominih novinarja praškega časopisa $\check{C} a s$ so ulični prodajalci časopisov v Pragi pogosto vzklikali: »Kar je belo, je resnica - kar je črno, je laž!« (Hajšman 1932: 31) Črno-žolti vojni cenzorji so bili pogosto živo poosebljenje izreka Viktorja Adlerja o Dvojni monarhiji kot celoti »Absolutismus, gemildert durch die Schlamperei $\ll$ (»Absolutizem, ublažen $s$ površnostjo «), in so kakšno od zgodb, ki so jo prepovedali v enem časopisu, dopustili objaviti v drugem (Orzoff 2004: 167, 179).

Po gromoglasni mobilizaciji je nastopila zlovešča tišina. Avstro-ogrski vladajoči krogi so upali, da jim bo z napovedjo vojne Srbiji uspelo povsem uničiti jugoslovansko gibanje kot popolnoma diskreditirano zaradi Principovega atentata in zadušiti tudi najmanjše iskre 
»veleizdajalskega « jugoslovanskega nacionalizma (Banjanin 1915: 20). Kmalu po izbruhu vojne so policijske oblasti začele izvajati po vseh avstro-ogrskih deželah z jugoslovanskim prebivalstvom najstrožja preganjanja z namenom, da svojim podanikom dajo lekcijo iz zvestobe dinastiji. Izvedene so bile številne hišne preiskave in vložene obtožnice zoper pripadnike nacionalistične mladine, zlasti intelektualce so množično pošiljali v internacijo. Interniranih je bilo okoli 100.000 ljudi, večinoma Slovanov. Zaradi »neprevidno « izgovorjene besede jih je bilo nekaj poslanih celo na strelišče in usmrčenih (Banjanin 1915: 20-1; Vošnjak 1916: 42; Lončar 1921: 94; Bartulović 1925: 46-58; Erjavec 1928: 221; Mal 1928: 1112). Precej uglednih Srbov so vzeli za talce (Banjanin 1915: 21). Malokdo je verjel, da bodo grožnjo z ubijanjem talcev uresničili. A se je zgodilo tudi to, da je bilo nekega dne ustreljenih šest, drugega dvanajst talcev. Da bi oblasti povečale učinek tega svojega zločina, so to »ogabno opravilo« naložile v izvedbo Bošnjakom (Blašković 1939: 82).

$\mathrm{V}$ aktih notranjega ministrstva so ohranjeni tudi podatki o številnih aretacijah, ki so jih izvedle civilne oblasti na Kranjskem zaradi posameznih protidržavnih dejanj, na primer širjenja italijanskega tiska $\mathrm{z}$ antantnimi vojnimi poročili, neizobešanja zastave ob zmagah avstrijske vojske, rusofilske in srbofilske izjave (do konca januarja 1915 je deželno predsedstvo poročalo o blizu 80 izjavah simpatij za Srbijo), tudi zaradi protivojnih izjav, izjav proti zavezniški Nemčiji in njenemu cesarju, ugovorov proti vojaškim posojilom in podobnem. Katerikrat je bil razlog za aretacijo že na robu smešnosti. Janko Pleterski navaja primer računskega svetnika Jožefa Koširja, ki mu je črni kruh, ki so ga prodajali na karte, povzročal prebavne težave. Košir je bil obsojen, ker je 14. decembra 1915 v pisarni vprašal: $\gg$ Jaz bi rad vedel, ali naš cesar tudi črn kruh jé? « Na opozorilo, da je to žalitev veličanstva, pa je odvrnil: »To je men vseen, entveder vsi glih al pa noben « (Pleterski 1971: 23). Številne obtožence so prignali pred naglo sodišče, kjer so jih obsojali na visoke kazni zaradi žalitve Veličanstva, motenja javnega reda in miru ter podobnih »zločinov «. Tako je bil, 24. avgusta 1915, v Suhem bajerju pri Ljubljani ustreljen Janez Brence, gostilničar iz Dovja. Ta je julija 1915 rekel, da je »nori cesar « začel vojno in da bi bilo boljše, če bi se povezali z Rusijo kot z Nemčijo. Sredi oktobra istega leta je bil obsojen na smrt in ustreljen kovač Janez Komar iz Radohe, ki je rekel: »Srbija ima prav! «(Pleterski 1971: 23).

Grožnja s strogim kaznovanjem ljudi ni odvrnila od tega, da so izražali svoje nestrinjanje. Po poročilu časopisa Marburger Zeitung je bil telefonski kabel ob progi, po kateri je potoval posebni vlak s posmrtnimi ostanki pokojnega prestolonaslednika in njegove soproge 
iz Trsta prek slovenskega ozemlja, pobarvan belo-modro-rdeče oziroma, kot piše avtor članka, v »slovensko-srbske « barve (Nepodpisano 1914e: 6). Še bolj provokativen je bil razglas mrtvim, naj vstanejo, ker Franc Jožef kliče vojake četrtega sklica v svojo vojsko. Razglas se je pojavil na dan vseh svetih leta 1914 na zidu mestnega pokopališča v Splitu. Zaradi tega zločina so oblasti razpisale nagrado v višini 1000 kron za informacijo o avtorju. Že naslednji dan je bilo mogoče na istem mestu prebrati vprašanje, ali bo nagrada izplačana v zlatu ali papirju (Buchan 1923: 226). Svoje nestrinjanje z vojno so ljudje znali pokazati tudi tako, da so zvesto spoštovali navodila oblasti. Ko so avstro-ogrske enote 2. decembra 1914 zmagovito vkorakale v Beograd, so oblasti v Zagrebu ukazale, da morajo meščani razobesiti zastave. Te so ostale razobešene še potem, ko so avstro-ogrske enote v begu izpraznile Srbijo. Ko je bil poraz tudi uradno priznan, je policija hodila od hiše do hiše in zahtevala, da zastave takoj pospravijo (Horvat 1967: 191).

Poostren nadzor in preganjanje pripadnikov nekaterih narodov večnarodnega cesarstva sta bila $\mathrm{v}$ oči bodečem nasprotju $\mathrm{z}$ bleščečo fasado patriotske evforije poseben tretma pripadnikov nekaterih narodov kot $\gg$ nezanesljivih «; prizadete narode je vse bolj odtujeval od državnih vojnih ciljev (Buchan 1923: 191-92; Cornwall 2000: 18). V vsesplošnem nezaupanju se je v vsakdanji rabi razvil »diplomatski« jezik. Bil je tako zavit, da se ni več vedelo, kaj pomeni izraz »naša « vojska: ali je to avstro-ogrska ali srbska. Namreč, če je kdo spraševal, kako gre naši vojski, in mu je sogovornik odgovoril: »Hvala Bogu, naši vojski gre dobro! «, je mogel občutiti, da se ta »hvala Bogu « nanaša na srbsko vojsko. Če pa je povedal, da je položaj srbske vojske slab, in pri tem namignil, je to pomenilo, da je bil položaj srbske vojske dober (Hribar 1929: 195).

\section{PRIČE VÉLIKEGA ČASA}

Vsedržavno ogorčenje prebivalstva zaradi sarajevskega atentata je zadoščalo za napoved vojne in uspešno mobilizacijo rezervistov. A potek vojne je to odločitev postavljal pod resen vprašaj. Naloga propagandne službe je bila odpravljati dvome, ki so se krepili sočasno z ohlajevanjem vojnega razpoloženja. Propaganda je poudarjala, da je bila zaradi srbskega ekspanzionizma (skupna) domovina v resni nevarnosti. Roke, ki so sicer ustvarjale izdelke za trg, so morale poprijeti za mrzlo železo in z njim moriti. Ko pa je bila vojna že dejstvo, jo je bilo treba izvojevati. Zakaj? Ker bi sicer domovina prišla pod tuje gospodstvo, njeni 
prebivalci pa vse svoje življenje ne bi več smeli priznavati svoje narodnosti in vere, oni in njihovi otroci ter otrok otroci bi namreč padli v suženjstvo »neizprosnih sovražnikov « (Peerz 1916b: 4-5). Kot je poudarjala avstrijska vojna propaganda, so namreč že pred vojno »naši sovražniki « tiskali zemljevide Evrope, na katerih ni bilo nič več videti ne Avstro-ogrske monarhije in ne Nemčije. Avstro-ogrsko ozemlje, »našo ljubo domačo zemljo «, pa naj bi si razdelili med seboj Rusi, Francozi, Italijani, Srbi in Romuni (Peerz 1916b: 7; 1917: 34).

Vojna je resda »najstrašnejše zlo «, vendar, so zatrjevali propagandisti, je v tem velikem, od sovražnikov vsiljenem boju »pravica na naši strani «, zato bo tudi končna zmaga naša. Dokler pa je vojna trajala, je bilo treba bodriti srca vojakov in civilnega prebivalstva z zagotavljanjem, da bo iz topovskega ognja izšla »nova Avstrija «, da se očem že kaže »zlata bodočnost « (Peerz 1916a: 23), ki bo nastopila, ko bo $\gg$ avstrijski orel krožil nad širnim osvojenim ozemljem in ko bomo dalje oboroženi namerili svoje korake proti deželi, v kateri je živel in trpel naš Zveličar «. Potem se bodo sami še kot starčki radi spominjali vojnih let, junaštva vojakov in njihovih izrednih dejanj pa se bodo spominjali in poveličevali še dolga stoletja, saj se poslej ne bo več pripovedovalo o junakih davnih dob ali o junakih tujih narodov, temveč le še »o naših slovenskih sinovih, ki so v svetovni vojni prelivali kri za domovino « (Peerz 1916a: 31-2).

Ob izbruhu vojne je ogromna večina ljudi pričakovala, da bo vojna ostala lokalizirana in bo v kratkem vsega konec. »Preden listje odpade, bomo doma, « so prepevali slovenski vojaki (Simčič 2014: 40). A trije meseci so trajali polna štiri leta, in v vojnem času so slepila o herojskih podvigih, kakor so jih upodabljali vojni slikarji iz časa » očeta « Radeckega, velikokrat umrla in herojskega junaka dokončno pokopala $\mathrm{v}$ »anahronističnih čitankah « (F. G. 1924: 1). Vojna leta so močno povečala slovenska pokopališča. $\mathrm{V}$ govoru uradne propagande in časopisnem jeziku so bili padli vojaki junaki, »ki so padli za sveto stvar «. Zato je bilo treba njihovo žrtev častiti, nikakor pa jih pomilovati (Flerè 1916: 43). Pedagoški pisatelj in kritik Pavel Flerè je »očetu « iz svoje knjige o avstrijski slavi v prvih dneh svetovne vojne položil v usta poduk, da vojna pač terja žrtve. Brez teh žrtev bi ne bilo dobrot, ki jih prinaša vojna. Ta naj bi namreč vse avstrijske narode povezala $\mathrm{v}$ »eno družino «, ki se s skupnimi močmi bojuje za svojo skupno domovino. Nadalje naj bi se v ognju na bojišču rodilo tudi bratstvo med različnimi sloji avstrijskega prebivalstva, da se je domovina krepila in rastla v slogi. - »To je dobrota vojne! « (Flerè 1916: 102-3).

Veliko število žrtev je že kmalu po začetku vojne spodbudilo razmišljanje o tem, kako naj se preživeli oddolžijo spominu tistih, ki 
so »za cesarja in državo « žrtvovali svoja življenja. Dnevnik Slovenec je že poldrugi mesec po začetku vojne opozoril, da je dolžnost njihova imena zapustiti tudi potomcem. Pisec kratke notice je domneval, da bodo $\mathrm{v}$ mestih postavljali bronaste spomenike vojskovodjem, pesniki in slikarji pa jim bodo posvečali svojo umetnost, a bodo kljub temu imena padlih vojakov v nekaj desetletjih utonila v pozabo. Da se to ne bi zgodilo, je predlagal, naj vsaka župnija imena padlih v boju ali onih, ki so podlegli ranam, ovekoveči v kamnu ali na kovinski plošči, postavljeni v cerkvi ali na kakšnem drugem prostoru. Po mnogih letih, ko bo vojna že davno del zgodovine, bodo take enostavne priče velikega časa nemo pričale o junaštvu naših vojakov «. Zato se je zavzel, da naj bi tudi najubožnejše župnije doprinesle »tako majhno žrtev « (Nepodpisano 1914s: 3).

Med véliko vojno je na raznih bojiščih za vedno obležalo okoli 35.000 slovenskih vojakov, medtem ko je morijo preživelo okoli 11.000 slovenskih vojnih invalidov. $\mathrm{Z}$ drugimi besedami, ob koncu vojne ni bilo nobene »vasi, ne slovenskega sela, kjer bi ne bili objokovali svojcev, ki jih je zakrila tuja gruda « (Dobida 1929: 430). Ogromno število žrtev ni ostalo brez vpliva na razumevanje smisla vojne. Po štirih strahotnih letih se je ta zaradi množice padlih vojakov v očeh večine slovenskih sodobnikov spremenila v štiriletno $\gg$ nesmiselno klanje «, v katerem so se slovenski vojaki bojevali in umirali na vseh mogočih evropskih, številni od njih tudi na azijskih in afriških bojiščih, ne da bi sami vedeli, zakaj. Če so to vedeli, so tudi, da se bojujejo » za koristi svojih zatiralcev, proti svojim lastnim koristim in koristim svo-

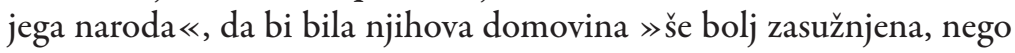
je bila do sedaj « (Nepodpisano 1918: 2). Ali, kot je nekaj let po koncu vojne zapisal Fran Govekar, slovenski vojaki v avstro-ogrski vojski so se »žrtvovali do najskrajnejših skrajnosti za to, da 'nas vzame hudič!' « (Govekar 1922: 1).

Po krvavi vojni so se zmagovalci in poraženci po večletnem smrtnem sovraštvu zbližali ob počaščenju vojnih grobov, kjer so izkazali spoštovanje in čast padlim vojakom vseh narodnosti, vseh bojišč, vseh bitk. Meddržavni dogovori so državam udeleženkam nalagali, da morajo urediti grobišča vojakov ne glede na njihovo narodno in državno pripadnost, temveč »primerno čutu hvaležnosti do svojih in čutu pietete kulturnega človeka do tujih vojakov, ki so žrtvovali v izpolnjevanju najtežjih dolžnosti do domovine svoje najdražje - življenje «. V ta namen so države udeleženke ustanovile poseben mednarodni sklad in vanj donirale »znatne vsote « (F. B. 1923: 3; J. H. 1923: 2). Nekaj let po vojni so v večjem delu Evrope »s priznanja in posnemanja vredno pieteto « uredili številna grobišča padlih vojakov ne glede na njihovo 
državno pripadnost (J. H. 1923: 2; Nepodpisano 1927: 3). Spomenike padlim vojakom so množično postavljali po mestih in vaseh širom evropske celine. Njihovo sporočilo je bilo, da je treba pomniti požrtvovalnost, trpljenje in imena padlih vojakov, izjema je bila država troimenega naroda, zato so nekateri $\mathrm{v}$ zvezi $s$ tem začeli govoriti kot $\mathrm{o} \gg$ naši sramoti« (F. B. 1923: 3; J. H. 1923: 2).

Po večletnem obdobju zamolčevanja padlih vojakov so se iz stiske svojcev, ki so bili prikrajšani za prostor spominjanja in žalovanja, oglasila mnenja, da je »sramotno «, da večina padlih vojakov ni imela niti skromne plošče z imeni v cerkvenem zidu ali na pokopališču, da v spomin vsem padlim vojakom še ni bilo niti najskromnejšega spomenika na javnem prostoru, da niso obhajali nobenih spominskih slovesnosti v njihovo čast. Pojavili so se javni pozivi, da so preživeli »dolžni hvaležno častiti spomin ne le onih, ki so padli kot borci proti Avstriji, ampak vseh, ki so pokopani v naši zemlji kot žrtve vojne, zlasti pa naših rojakov, ker so naši, ker so za nas in zaradi nas trpeli, ker je tudi iz njihovih grobov vzklila naša svoboda «.

Dosti bodi brezbrižnosti! Imamo zvonove, popravili smo cerkve in domove, zdaj hočemo in moramo na delo, da popravimo grobove zapuščenih bratov, da v naše cerkve vzidamo plošče, na pokopališča in trge postavimo spomenike $\mathrm{z}$ imeni naših mučenikov. Na častno delo krščanske in narodne hvaležnosti kulturnega naroda! Župnije, občine, društva, svojci padlih, vsi, ki vas peče vest vsled zanemarjene dolžnosti, poskrbite za grobove, pokopališča, vzidavajte spominske plošče z imeni, stavite spomenike, poskrbite vsako leto za sveto daritev bratom, ki počivajo $\mathrm{v}$ tujih deželah morda brez groba in križa! (J. H. 1923: 2)

Konec vojne je med narode, izmučene od dolgotrajne vojne, neizogibno prinesel nove realnosti s pozabami. Med obdobjem pred vojno in tistim po njej je zdaj zazijal »prepad, čez katerega ni mostov in ki drug drugega dosegata samo še po rahlih spominih « (Nepodpisano 1939b: 1). Kolektvni spomin na vojno, njene vzroke in posledice ter njene cilje in smotre. Pravzaprav se narativna podoba o vojni iz časa po koncu vojne tako razlikuje od tiste iz časov med vojno, kot da bi šlo za dvoje povsem različnih vojn s povsem različnimi motivi, cilji in posledicami. Po koncu prve svetovne vojne in ustanovitvi nacionalne države troimenega naroda je nova državna skupnost potrebovala svoje heroje in simbole kot družbeno vezivo. Eden od najpomembnejših smotrov, ki jih zasledujejo nacionalne države pri izvajanju spominskih svečanosti, je vzdrževanje in zagotavljanje enotnosti »zamišljene skupnosti « ter $s$ tem povezanimi narativi in rituali (Ashplant 2000: 263). Tako je Gavrilo Princip, na primer, iz gnusnega atentatorja postal simbol 
herojskega Srba in jugoslovanskega rodoljuba, ki je žrtvoval svoje življenje za svobodo vseh južnih Slovanov in obnovo padlega srbskega kraljestva (Gerolymatos 2002: 14).

\section{PREPAD BREZ BRVI}

$Z$ vprašanjem smisla vélike vojne so se na poseben način soočali tudi državljani prve skupne države južnih Slovanov. Njihovo (samo)spraševanje in iskanje pravih odgovorov sta dodatno obremenjevalo dejstvo, da so se tedanji državljani države naroda s tremi imeni v vojnih letih bojevali kot pripadniki sovražnih vojska. Že samo to dejstvo je bilo dovolj visoka ovira za dosego soglasnega »uradnega « spomina na vojno. Še večji problem je predstavljalo drugo dejstvo, namreč, da teh vprašanj niso nikoli zares in premišljeno tematizirali, temveč so jih prepustili stihijski mešanici zmagoslavnega (samo)zadovoljstva na eni strani in zmedenega iskanja svoje olepšane podobe na drugi.

$\check{Z}$ e v času vojne je profesor slavistike na berlinski univerzi Alexander Brückner ocenjeval, da bo neizogibna posledica svetovne vojne, v kateri so se slovanski vojaki pogosto vojskovali na nasprotnih straneh bojnih črt, oznanila »konec panslavizma « (Brückner 1916: 15). Brückner o posledicah vojne za občutje skupnosti med Jugoslovani ni razmišljal: v letu 1916 je bilo težko misliti na razpad Dvojne monarhije; tedaj niso resno mislili na to niti v vrstah zavezniških sil. Vendar se je zgodilo prav to, novoustanovljeno Kraljestvo Srbov, Hrvatov in Slovencev je v eni državi združilo »zmagovalce « (nekdanje državljane Kraljevine Srbije) in »poražence « (nekdanje državljane Dvojne monarhije) (glej Dimić 1998: 33).

Zmaga v vojni je le redkokdaj v zgodovini zmagovalce privedla na pot samoodrekanja. Potemtakem ni popolnoma nepričakovano, če so srbski politični in vojaški voditelji pristopali $k$ reševanju tekočih političnih, ekonomskih, družbenih in kulturnih vprašanj v novoosnovani skupni državi Jugoslovanov skozi prizmo svojih lastnih interesov. Tako je eden od poznejših članov bosansko-hercegovske vlade dr. Milan Jojkić prihod srbske vojske v Sarajevo leta 1918 opisal kot veličastno zmago, plačano z ogromno krvi, in »kronanje ideje svobode in ujedinjenja enotnega jugoslovanskega naroda Srbov, Hrvatov in Slovencev « (Jojkić 1918: 33). Dopisnik Dušan Lončarević pa podobno, namreč da je bila srbska vojska vse do zedinjenja Srbov, Hrvatov in Slovencev up Kraljevine Srbije in sploh vsega troimenega naroda. $Z$ velikanskim naporom in neprekosljivim junaštvom je srbska vojska ne le obranila 
narod v Srbiji, temveč raztrgala stoletne okove zasužnjenih bratov in izbojevala svobodo celotnemu narodu, za kar ji bo troimeni narod ostal » večni dolžnik « (Lončarević 1919: 32).

Vojni pohod Avstro-Ogrske nad Srbijo, v katerem so bili na strani napadalcev v velikem številu mobilizirani Hrvati, manjkalo pa ni niti Slovencev, Bošnjakov in Srbov, je imel za posledico ogromno žrtev in hudo ekonomsko škodo v napadeni državi. Kronisti so Srbijo slikali kot » skelet «, kot razrušen in opustošen » vojaški tabor «. Srbski kolektivni spomin na bratomorno in versko vojno je ostal vir nezaupanja, ki je v veliki meri krojil tudi povojno politiko (Dimić 1998: 30-2). Negativnih posledic bratomorne vojne, zlasti v Srbiji, vodilni politiki niso mogli izbrisati iz zavesti ljudi, so jih pa večkrat zlorabljali v povojnih političnih bojih (Petranović 1980: 1980: 33). Z množenjem povojnih let so se množile tudi kritične besede na rovaš bojevanja Hrvatov in Slovencev na poraženi strani. Politične in ekonomske krize, ki so se nizale druga za drugo, so množile nesporazume in nesoglasja v javnem govoru, ki so se neredko reševala $\mathrm{z}$ instrumentalizacijo žrtev vojne. Izkoriščanje spomina na vojna leta s strani političnih strank, ki so bodisi bahavo poudarjale jezero prelite srbske krvi bodisi so srbske žrtve ošabno omalovaževale, je desetletje po koncu vojne pripeljalo $\mathrm{k}$ popolni blokadi političnega življenja (Manojlović Pintar 2014: 140-41). Poudarek na delitve iz medvojnih let je bil slab temelj za izgrajevanje zavesti o pripadnosti eni skupnosti, ki mora temeljiti le na tem, kar pripadniki skupnosti skupaj pomnijo in skupaj pozabijo (Renan 1882:7-8).

To delitev bi, seveda, politične stranke presegle, če bi glede pomembnih vprašanj njihovi interesi bili bolj komplementarni. Zdi se, da je v svojem zapisu ob dvajsetletnici ustanovitve skupne države Bogumil Vošnjak imel v mislih prav to, ko je razmišljal, da nacionalna država rabi »kult žrtve«. Vošnjak je ugotavljal, da nobena država v svetovni vojni ni žrtvovala toliko kot Srbija, zato tudi ne bi smeli »nikdar pozabiti, koliko krvi je bilo prelite za zmago «. Ampak, je dodal, teh žrtev ne smejo izkoriščati prav tisti, »ki so najmanj žrtvovali, za dosego hegemonije in materialnih ugodnosti« (Vošnjak 1938: 46).

Srbske izgube so bile resnično ogromne. Svet je plačal vojno z milijonskimi žrtvami, pri čemer je bil delež, ki ga je prispevala »mati junakov, Kraljevina Srbija «, nesorazmerno velik: žrtvovala je skoraj milijon človeških življenj od štirih milijonov prebivalcev, ki jih je štela pred vojno (Šišić 1937: 267). Natančnega števila srbskih žrtev nikoli niso ugotavljali, a uradno poročilo z mirovne konference $\mathrm{v}$ Versaillesu iz leta 1919 navaja, da je Kraljevina Srbija v prvi svetovni vojni izgubila 1.247 .435 prebivalcev, od tega 845.000 civilistov in 402.435 vojakov (Protić 2006: 50; 2009: 219). Po navedbah zgodovinarja Branka 
Petranovića pa je Srbija, ki je pred vojno štela štiri milijone prebivalcev, med vojno izgubila približno 370.000 vojakov. Nadaljnjih 630.000 ljudi je umrlo zaradi kolere, lakote in težkih življenjskih pogojev v taboriščih za vojne ujetnike. Vojno je preživelo okoli 114.000 vojnih invalidov, 500.000 otrok pa je ostalo brez staršev (Petranović 1980: 35).

Vlada in prebivalstvo nekdanje Kraljevine Srbije so vstopili v novonastalo skupno državo Srbov, Hrvatov in Slovencev z zavestjo, da so zmagali v krvavi vojni. Številni med njimi so gledali na Hrvaško in Slovenijo kot na osvobojeno in odcepljeno ozemlje v vojni poraženih, ki se sami niso zmožni braniti pred pohlepnimi sosedi. Zaradi svojih žrtev, pretrpljenih med vojno, in svoje junaške preteklosti je srbsko prebivalstvo pričakovalo vodilni položaj v novi državi. Vendar srbski državniki niso znali ohraniti potrebnega takta, in so od osvobojenega prebivalstva takoj začeli izterjevati davek spoštovanja in hvaležnosti. Premier Nikola Pašić je nenehno in javno razvijal idejo, da Srbija mora osvoboditi Hrvate in Slovence, ne nazadnje mora to biti temelj skupne države. Po oceni Milade Paulove pa je prav to porušilo ravnotežje in ranilo hrvaški narodni ponos (Paulová 1924: 292). Nekdanji predsednik Jugoslovanskega odbora in prvi zunanji minister skupne države Ante Trumbić je v svojem elaboratu o hrvaškem vprašanju iz leta 1932 zapisal, da tudi tisti tujci, ki ne poznajo dovolj jugoslovanskih razmer in njihovega pravega vzroka, menijo, da je v primeru Jugoslavije šlo za »nesrečen zakon «. Po Trumbićevi pikri oceni se Srbi iz vélike vojne niso ničesar naučili in nič pozabili, le v Beogradu sta se močno povečali objestnost zaradi nepričakovane sreče in megalomanija brez meja (cit. Boban 1989: 27).

Kot dobro ponazarja izjava Stojana Protića, enega vodilnih članov srbske radikalne stranke, Trumbićeva pikrost ni bila neutemeljena. Protić je namreč menil, da se še nikoli v zgodovini vojskovanja ni zgodilo, da bi zmagovalec hranil poraženca. Po njem bi bilo $\gg$ to kardinalna in katastrofalna politična napaka «, saj v nobenem primeru zmagovalec »ne more in ne sme « hraniti poraženega, temveč mora vedno poraženi hraniti zmagovalca, ne glede na to, kdo je močnejši ali socialno šibkejši: »Deviza poraženi mora hraniti, vzdrževati in poslušati zmagovalca, to je aksiom « (cit. Protić 2006: 129-30). Za državljane skupne jugoslovanske države, ki so se vojskovali v avstro-ogrskih uniformah, ta ista preteklost nikakor ni vir ponosa, prav nasprotno. Louis Adamič, denimo, je med svojim obiskom v Jugoslaviji na začetku 1930-ih let opažal, da so po združitvi s Srbi bili Hrvati in Slovenci » precej malodušni «, saj so se mnogi med njimi borili na avstrijski strani (Adamic 1934: 248).

General v srbski vojski Pavle Jurišić Šturm, nekdanji adjutant kralja Petra I. Karađorđevića, je leta 1924 objavil knjigo, v kateri je 
predstavil svoje poglede na aktualna politična vprašanja. $\mathrm{Z}$ njegovega vidika je bilo očitno predvsem, da so novoustanovljeno nacionalno državo tvorili zmagovalci in poraženci (Jurišić 1924: 48). Govorjenje, da se država ne sme deliti na zmagovalce in poražence, je predstavljalo, po generalovih besedah, veliko » zablodo in iluzijo «. Srbska in avstro-ogrska vojska sta se vojskovali v znamenju dveh nasprotujočih si ideologij, je razlagal general. Ena je bila »naša « (osvoboditev in ujedinjenje vseh Srbov, Hrvatov in Slovencev v svobodno narodno državo), druga ideologija pa je bila tej popolnoma nasprotna, delovala je proti osvoboditvi in ujedinjenju v neodvisno narodno državo (Jurišić 1924: 47-8). Po generalovem mnenju tudi ne bi bilo prav zanikati, da so bili poraženci oni, ki so si v imenu nekake »habsburške Jugoslavije « in pod geslom »Srbe na vrbe « (Jurišić 1924: 5) prizadevali, da bi uničili majhno Kraljevino Srbijo kot jugoslovanski Piemont (Jurišić 1924: 48), ali da so tisti, ki so se »zavestno in razkošno žrtvovali v službi te naše velike narodne ideje «, zmagovalci, in to še zlasti v novi državi, nastali v znaku zmage te velike ideje. Če v véliki vojni ni bilo ne zmagovalcev ne poražencev, argumentira Jurišić Šturm, bi se morali vprašati, zakaj so se sploh bojevali in posejali toliko grobov. Dodaja, da se sam $s$ tem nikakor ne strinja, in izraža prepričanje, da bi bilo z nacionalnega stališča táko stališče enako »bankrotu naše povojne demokracije pred separatisti « (Jurišić 1924: 49-50).

Politik Stojan Protić in general Pavle Jurišić Šturm nikakor nista bila osamljena v teh svojih stališčih. Ernestu Kruleju, dobrovoljcu v srbski vojski, je 1. junija 1918 vojni invalid, Srbijanec, sicer njegov dobri prijatelj Joca Kočić, pokazal pesmico neznanega avtorja s satirično upodobitvijo Jugoslovanov. Takole se glasi:

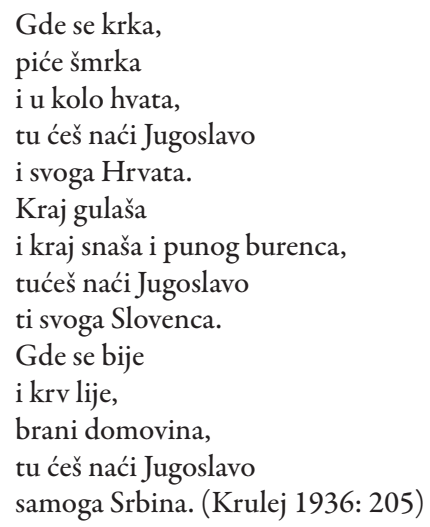

Prevedeno v jezik tedanje politične realnosti je to pomenilo, da srbska politična in gospodarska elita ni bila pripravljena deliti 
oblasti. Zato nacionalistične parole o državi zmagovalki in članici zmagovitega tabora, ki nima nikakršne potrebe deliti oblast $s$ komer koli, še zlasti pa ne s poraženci, ki so bili v času vojne v sovražnem taboru in zato tudi nimajo nobenih zaslug za ustanovitev nove države (Janković 1983: 389-90).

\section{SPOMIN NA VELIKO VOJNO KOT USTANOVNI MIT}

Po koncu vélike vojne je nacionalna država Naroda s tremi imeni interpretirala tako heroizem ljudi kot njihove žrtve s pomočjo imaginarija in simbolike kosovskega mita. Aleksander Karađorđević (prestolonaslednik in regent 1918-1921, kralj 1921-1934) je bil aktivno vključen v oblikovanje povojnega javnega spomina na srbsko vlogo v véliki vojni. Osebno je prisostvoval na številnih vidovdanskih proslavah in podobnih spominskih svečanostih, na njih je večkrat nastopil kot glavni govornik. V svojih govorih je poudarjal velike srbske žrtve za ustanovitev jugoslovanske države (Bokovoy 2001: 248, 251).

V nacionalni državi južnih Slovanov so dobile spominske svečanosti ob pomembnih zgodovinskih obletnicah in na prizoriščih zmagovitih bitk srbske vojske in dobrovoljcev državotvorni značaj. V nacionalni državi troimenega naroda so gojili kot državotvorni spomin srbsko in dobrovoljsko vojaško tradicijo, medtem ko je bil po osvoboditvi in ujedinjenju spomin na avstro-ogrsko vojaško tradicijo potisnjen $\mathrm{v}$ pozabo, s tem pa tudi žrtve vojne, ki so padle v avstro-ogrskih uniformah, kot žrtve za tujo, v vojni poraženo vojsko (glej npr. Bokovoy 2001: 251). Čeprav so bile žrtve na srbski strani večje, so veterani srbske vojske imeli za razliko od veteranov avstro-ogrske vojske vsaj zadoščenje, da njihovo trpljenje in požrtvovalnost nista bila zaman; z njima so namreč dosegli osvoboditev in ujedinjenje južnih Slovanov. Spominske svečanosti ob obletnicah pomembnih bitk so imele za cilj blaženje travm, ki jih je zapustila vojna. Napad avstro-ogrske vojske, poraz, umik, okupacija in na koncu zmaga $\mathrm{v}$ vojni proti premočnemu nasprotniku so postali elementi srbske narativne podobe o vojni, ki so dajali smisel vojnim izkušnjam. Avstro-ogrski veterani v tej podobi niso imeli enakovredne vloge. John Paul Newman navaja primer hrvaškega vojnega veterana, ki je zaprosil za finančno podporo. Uradnik ga je vprašal, če je bil solunski borec, in ga poslal k cesarju Karlu, češ, morda ti bo on dal kaj (Newman 2011: 56-7).

Po koncu vojne med državljani novoustanovljene nacionalne države ni bilo enotnega spomina na vojna leta, ampak je med njimi 
krožilo več zgodb, tudi protislovnih. Uradno spominjanje na véliko vojno in komemoracije v slavo padlih vojakov je spominu na vojna leta dodalo politično dimenzijo, in sicer $\mathrm{v}$ vprašanjih, katera stranka bo $\mathrm{v}$ borbi za oblast svojo zgodbo javno artikulirala, katere zgodbe bodo ostale v sferi privatnega, fragmentirane ali potlačene ter katere bodo dobile svoje mesto in priznanje v javnosti (prim. Ashplant, Dawson in Roper 2000: 16). Na dolgi rok je to stanje postalo hud kamen spotike. $\mathrm{Na}$ razdiralno moč čustev, sproženih v tem procesu na strani »poražencev «, je Slovenec opozarjal v uvodniku prvonovembrske številke leta 1924. Po mnenju pisca so zaradi $\gg$ sedanjih razrvanih političnih in socialnih razmer « ti praznični dnevi postali »še posebno resen in velik opomin, ki nas bo vse jako drago stal, ako ga bomo še dalje prezirali« (Nepodpisano 1924: 1). Zgodilo se je prav to.

Srbske elite so bile trdne v prepričanju, da je njihova zgodba o junaškem odporu zoper močnejšega agresorja, trpljenju naroda, mučeništvu srbske vojske in njeni končni zmagi tako lepa, da ne potrebuje nobene dopolnitve ali celo spremembe. Zgodbo so petrificirali številni spomeniki, posejani po srbskih mestih in vaseh. Ministrstvo za verske zadeve in kraljevi dvor sta finančno in moralno podpirala iniciative za postavitev spomenikov padlim vojakom. Srbske veteranske organizacije so pogosto, zlasti neposredno po koncu vojne, postavljale spomenike kralju Petru I., osvoboditelju južnih Slovanov. Priljubljeni so bili tudi lokalni spomeniki padlim vojakom in spomeniki, postavljeni v spomin na določene večje bitke. Organizacije srbskih veteranov, ki so skrbele za postavljanje teh spomenikov, so balkanske vojne in prvo svetovno vojno predstavljale kot enoten konflikt. Zato so na spomenike vklesavali letnice 1912-1918 in napise »oslobođenje i ujedinjenje «, ker naj bi bila osvoboditev in združitev vseh južnih Slovanov cilj in rezultat teh srbskih vojn (Newman 2015: 57).

$\mathrm{V}$ delu nove skupne države, ki je pripadal predvojni Kraljevini Srbiji, se je tedaj uveljavila interpretacija vojne, postavljene v srbski nacionalni okvir z močnimi biblijskimi konotacijami. $\mathrm{V}$ tej interpetaciji je bila prva svetovna vojna boj Davida proti Goljatu z dramatičnim vrhuncem trpljenja med umikom srbske vojske prek albanskih gora in slavnim vstajenjem naroda na koncu zgodbe. Vojna je bila vgrajena v jugoslovansko pripoved kot najpomembnejši zgodovinski dogodek, na katerem je temeljilo oblikovanje skupne države (Troch 2015: 91).

Postavljanje spomenikov osvoboditvi in združitvi ter komemoracije, povezane z njimi, je bilo namenjeno osveščanju prihodnjih generacij, kako pravilno razumeti žrtve, na katerih je bila zgrajena skupna država. Kot nekakšne trofeje so vojni spomeniki razglašale srbske zahteve v zvezi z novoosvobojenimi področji: »a-nacionalne« 
elemente so opominjali, kdo je bil zmagovalec v vojni in komu pripadajo osvobojena ozemlja. Kot ugotavlja John Paul Newman, je imel celotni komemorativni cikel osvoboditve in združitve svoj začetek na jugu države, kjer so srbske vojaške enote dosegle svoje prve srbske zmage v balkanskih vojnah. Leta 1922 je proslava desetletnice zmage v bitki pri Kumanovu predstavljala začetek vala vojnih komemoracij, ki je trajal skoraj eno desetletje (Newman 2015: 88). Srbiziranje juga je bil neprikrit namen teh komemoracij. Tako je bilo odkritje spomenika $\mathrm{v}$ Skopju za vojake, padle v letih od 1912 do 1918 , na pobudo Združenja demobiliziranih solunskih borcev v Skopju hkrati tudi priložnost za opominjanje ljudstva o srednjeveški srbski dediščini Skopja. Kot je povedal predsednik združenja Mladen Živanović, so Srbi čakali več kot petsto let, da so postavili ta spomenik, prvi v mestu po osvoboditvi in združitvi, ki bo služil kot »tempelj pobožne hvaležnosti «, padlim v letih od 1912 do 1918 (Newman 2015: 88-9).

Po koncu vojne so zrasli številni spomeniki osvoboditvi in združitvi na ozemlju predvojne Kraljevine Srbije, medtem ko je bilo v krajih zunaj Srbije teh postavljenih le malo. V Ljubljani, denimo, so že kmalu po koncu vojne začeli akcijo zbiranja sredstev za postavitev spomenika zmage in zedinjenja Srbov, Hrvatov in Slovencev, s katerim so hoteli počastiti spomin na »brate «, ki so padli v bojih za »našo osvoboditev« (Nepodpisano 1920: 6). A spomenika niso nikoli postavili. Narodnjaki so spravili domov in s častmi pokopali nekaj upornikov iz Judenburga, na pokopališču pri Sv. Križu v Ljubljani je bil postavljen »spomenik borcem za svobodo «, vojaki, ki so padli kot pripadniki avstro-ogrske vojske, pa so bili potisnjeni iz uradnega spomina in prva leta po vojni niso bili deležni nobenega spominskega obeležja. V slovenskem časopisju so se pojavila celo razmišljanja, da slovenski narod sploh nima herojev, češ: » Mi smo narod Črtomirov, ki se je dal krstiti na Jezerskem otoku. Mi smo narod Primoža Trubarja, ki je bežal in v prognanstvu umrl, in ki ni bil heroj ...« (Oblak 1920: 1)

Zveza slovenskih vojakov je redno prirejala spominske svečanosti ob odkritjih spominskih znamenj in določenih dnevih, zlasti ob prvonovembrskih praznikih. Podobno kot drugje po Evropi so tudi slovenski spomeniki »padlim vojakom, ki ne bodo nikoli umrli«, postali simboli žrtvovanja za slovenski narod. Spominske svečanosti za slovenske vojake, padle v avstrijski uniformi, so potekale ob različnih priložnostih bodisi ob slavnostnih odkritjih spomenikov bodisi na določene, pomembnejše dneve, vedno pa sta jih spremljala vihranje zastav in igranje himne. Tako so utrjevale liturgijo slovenskega nacionalizma.

Vélika vojna je povzročila velikansko prelomnico v slovenskem kolektivnem spominu. Še v prvem vojnem letu se je 16. in 17. avgusta 
1915 udeležilo »narodnega romanja « k Mariji Pomagaj na Brezje več tisoč pripadnikov »Marijinega ljudstva «. Tako so skupno proslavili cesarjevo petinosemdesetletnico in molili za »naše junaške vojake $v$ bojni črti in srečno bodočnost našega naroda « (Nepodpisano 1915a 1; 1915b: 1; 1915f: 4; 1915g: 484). V pozivu »Zakaj še na Brezje?«, objavljenem sredi avgusta 1915, je Domoljub zapisal, da se bodo zbrani na »cesarjev dan « spominjali cesarja in molili »za svoje drage na krvavih bojnih poljanah, da bi jih varovala Kraljica vojnih trum, da bi jih vodila od zmage do zmage «, pa tudi »za može in mladeniče, ki že leže v tuji zemlji« (Nepodpisano 1915c: 462).

Žalne slovesnosti, prirejene v spomin padlim vojakom, so potekale ob glasnem poudarjanju svoje nepolitičnosti, a so imele eno opazno skupno točko: mobilizacijo množic za določene politične cilje. Zborovanja ob odkritjih spominskih obeležij ali ob spominskih svečanostih so redno vključevala izražanje političnih stališč, zlasti slavnostnih, vendar ne o preteklosti, temveč o sedanjosti. V nacionalni državi troimenega naroda, $v$ kateri so bili njeni današnji državljani včeraj na nasprotni strani bojnih črt, je spomin na vojno postal eno osrednjih političnih bojišč. Z leti je ta boj postajal vse bolj jasno in glasno političen; kot je zapisal Osrednji odbor Zveze bojevnikov, so se sredi prve polovice tridesetih let njihova zborovanja spremenila $\mathrm{v} \gg$ prave narodne manifestacije « (Osrednji odbor Zveze bojevnikov 1933: 3). Govorniki na zborovanjih nekdanjih bojevnikov so poudarjali, da hočejo in morajo ohraniti slovenski jezik, slovenske narodne posebnosti in katoliško vero (glej npr. Nepodpisano 1934a: 1; 1934e: 4; 1935e: 1; A. L. 1934: 3).

Komemoriranje slovenskih vojnih žrtev je nudilo priložnost za pomiritev z jugoslovansko nacionalno državo, saj je italijanska grožnja ostala živa tudi po koncu vojne. Prelomni značaj vélike vojne v zgodovini Slovencev in veličina njihovih vojnih žrtev pa nista dobila svojega mesta v komemoracijah in svečanostih, prirejenih $\mathrm{v}$ spomin na vojno $\mathrm{v}$ skupni državi. Posledica je bila, da so Slovenci, ki niso mogli artikulirati svojega spomina na svoje vojne žrtve znotraj koncepcije osvoboditve in ujedinjenja (Newman 2015: 167), zato začeli iskati drug in drugačen okvir. Novi okvir osmišljanja postavljavljanja spomenikov slovenskim padlim vojakom je bil na deklarativni ravni počastitev spomina padlih tovarišev kot znak pietete, ki jo goji kulturni narod v odnosu do svojih sinov (Bonač 1931: 1-2; K. M. H. 1935: 1).

Spomeniki padlim vojakom so svojcem in bližnjim omogočali, da so žalovali in slavili mučeništvo padlih vojakov; to pa ni šlo brez političnih nasledkov za žive. Spominske svečanosti ob spomenikih padlim vojakom resda niso odpravile političnih razlik med udeleženci, so 
pa pogosto izzvenele v vsaj navidezni enoglasnosti. Slavnostni govorniki so redno poudarjali potrebo po enotnosti in notranji slógi. Ohranjanje spominov na trpljenje $\mathrm{v}$ vojni in spominske svečanosti, prirejene $\mathrm{v}$ čast padlim vojakom, so tako postali izraz prizadevanja določenih skupin, da bi javno artikulirale svoje poglede na preteklost in pridobile zanje širše družbeno priznanje. Spomeniki, je pojasnjeval uvodničar v Gorenjcu, predstavljajo zgodovinsko vrednost, ker je v njih ovekovečena določena ideja, ki je narodu kažipot. $\gg V$ spomenikih narod manifestira, ker si hoče dati duška, v spomenikih narod tudi protestira, zato mu je treba dati poguma, « pravi pisec. »In zato postavljamo spomenike« (K. M. H. 1935: 1).

\section{POLITIKA SPOMINJANJA NA TRPLJENJE V VOJNI}

Postavljanje spomenikov padlim vojakom avstro-ogrske vojske je bilo odvisno od posameznikov oziroma manjših skupin, ki so znali mobilizirati ljudi, se dogovoriti za obliko spomenika in prostor postavitve. Najpogostejša oblika je bila spominska plošča, ki so jo praviloma vzidali na steno cerkve ali obzidje pokopališča, imena padlih vojakov so bila vklesana tudi na likovno bolj zahtevnih spomenikih. Imena, praviloma razvrščena po abecednem vrstnem redu, so ohranjala enakost, domnevno vzpostavljeno na bojiščih, vsi padli so bili na ta način razglašeni za junake (Van Ypersele 2010: 580). Na spomenikih in spominskih znamenjih vklesana imena so vsem padlim izkazovala čast, nekdaj namenjeno zgolj lokalnim veljakom. V trajen material vklesana in $\mathrm{z}$ zlatimi črkami izpisana imena, ki so zasebno vzbujala v ljudeh žalost, ugotavlja Catherine Moriarty, so na ta način postala vir državljanskega ponosa (Moriarty 1997: 138). Sodelovanje faranov in/ali vaščanov pri velikih javnih spominskih svečanostih pa je utrjevalo vlogo kmetstva kot odločilnih pripadnikov naroda.

Spomin na slovenske vojake, padle v avstrijski uniformi, je organizirano gojila »nadstrankarska in nepolitična « zveza bojevnikov, ki je imela svoj prvi občni zbor »okrog prestola nebeške Kraljice « na Brezjah leta 1924. Zveza si je nadela nalogo združiti vse tovariše iz vojne, da bi skupno počastili spomin padlih tovarišev, se skupno zavzeli za vojne invalide ter obnovili duh tovarištva in ljubezni, kot sta vladala nekoč v strelskih jarkih (Nepodpisano 1934b: 2). $\mathrm{Na}$ njeno pobudo so nedeljo za nedeljo odkrivali spominske plošče po župnijah v Dravski banovini (Stelè 1931: 412), do leta 1926 je bilo postavljenih že približno 150 spomenikov padlim »slovenskim 
junakom « (Nepodpisano 1926: 6; Dobida 1929: 430; Bonač 1931: 1-2). Ti naj bi bili »trajna priča našim zanamcem o pieteti do naših padlih tovarišev in kulturi našega naroda, ki se je ravnal po izreku: »Narod, ki svoje mrtve ceni in spoštuje, si bodočnost zlato kuje « (Nepodpisano 1934b: 2). Poleg manjših spomenikov po vaseh in župnijah je tajnik Bonač že leta 1926 napovedal, da bodo postavili »dostojen, velik, splošen spomenik v Ljubljani, v Tivolskem parku, vsem žrtvam vojne « (Nepodpisano 1926: 6).

Sredstva za spomenike so zbirali po posameznih vaseh in župnijah v obliki prostovoljnih prispevkov. Ker so teh le redko zbrali dovolj za pokritje vseh stroškov za postavitev spomenika, so na dan odkritij spomenikov večkrat organizirali veselice s plesi, srečolovom, šaljivo pošto, licitacijami in podobnim. Zveza slovenskih vojakov je karala tako prakso kot oskrumbo spomina padlih vojakov, hkrati pa pozivala nekdanje vojake, »naj ne puste plesati na grobovih in kosteh naših padlih tovarišev «. Ali povedano drugače, če kaka občina ne more postaviti spomenika na »dostojen način «, naj ga rajši ne postavi (Glavni odbor ZSV 1925: 2). Ta in drugi podobni pozivi pa so naleteli na bolj gluha ušesa: veselice so ostale še leta priljubljen način prepričevanja svojcev padlih vojakov, naj bolj široko odprejo svoje denarnice. Svečana odkritja spomenikov padlim vojakom širom banovine so krepila »tovarištvo iz vojne, rastel je duh sloge in vzajemnosti « (Nepodpisano 1934b: 2). Večina prebivalstva je delovanje zveze nekdanjih slovenskih vojakov spremljala s simpatijami, po drugi strani pa so se ves čas oglašali očitki »avstrijakantstva « (Nepodpisano 1926: 6; 1934b: 2; 1934c: 3; 1934f: 1), čeprav je leta 1924 Francè Bonač neustrašeno povedal:

\footnotetext{
Enkrat za vselej glasno povemo: Če smo bili do konca zvesti svoji sveti vojaški prisegi v tuji, nenaklonjeni nam državi, še bolj bomo v mili, domači, zlasti če bo šlo za svete pravice naše domače grude in naroda, ne pa za umazane špekulacije onih, ki jim je vojna le ugodna prilika za nasičenje lastnih žepov. Zapomnijo naj si vsi, da med prejšnjo Avstrijo in sedanjo Jugoslavijo leži krvavo jezero svetovnega požara in da je to jezero korenito spremenilo mišljenje ljudstev Evrope in tudi našega naroda. In uprav zato postavljamo spomenike in častimo blaženi spomin onih, ki so plavajoč po tem strašnem jezeru in odrivajoč od nas besne valove, ki so grozili, da nas pogoltnejo vse, sami izginili in se potopili. Zato so nam njihova revna grobišča povsod mejniki življenja. Vojak svetovne vojne je bil trpin vsak, pa najsi je bil te ali one narodnosti. (Bonač 1924: 2)
}

Tako kot v začetni fazi slovenskega nacionalizma so tudi slovenski bojevniki politično naravo svojega gibanja zavijali v celofan zvestobe in vdanosti kraljevi hiši. $\mathrm{Z}$ vseh shodov, občnih zborov in 
podobnih prireditev ter srečanj združenja slovenskih vojakov so redno pošiljali vdanostne brzojavke kralju Aleksandru, v katerih so poudarjali nadstrankarsko in nepolitično naravo svojega delovanja. Občasno pa so kraljevo ime tudi povezali z imeni padlih vojakov, $s$ čimer so jim dali očitno olepšano interpretacijo njihove zgodovinske vloge in pomena. Tako je krajevna organizacija Boj v Vodicah prenovila spomenik v vojni padlim vojakom iz svoje občine, s katerega je dež spral vse črke. Leta 1935 so imena padlih vojakov pozlatili, na odlično mesto na spomeniku pa vklesali še ime kralja Aleksandra I. Zedinitelja (Nepodpisano 1935a: 3).

Združenje slovenskih vojakov je $\mathrm{v}$ različnih organizacijskih oblikah spodbujalo postavljanje spomenikov padlim tovarišem ter prirejalo spominske svečanosti in shode. Posebej pomembni so bili tabori bojevnikov iz svetovne vojne na Brezjah, ki so potekali sredi avgusta, tedaj v istem času, kot so med vojno prirejali romanja na čast cesarjevega rojstnega dneva, le da so bili po vojni posvečeni Marijinemu prazniku. Nemara največji zbor bojevnikov je potekal na mali šmaren 1925. Po ocenah je na zbor prišlo okoli 12.000 udeležencev iz vseh slovenskih pokrajin, tudi zunaj Kraljevine Srbov, Hrvatov in Slovencev. Med njimi pa ni bilo predstavnikov politične oblasti, saj se na vabilo ni odzvala. Ob tej priložnosti so padlim slovenskim vojakom odkrili spominsko ploščo iz kararskega marmorja in švedskega granita, vzidano v sredi med Marijino kapelico in ostalim svetiščem tako, da je vidna po celi cerkvi. Na plošči je upodobljena Kristusova glava, spodaj umirajoči lev, vmes napis z zlatimi črkami: »Vojnih grozot oteti, / kličemo Kraljico miru: / Padlim pri Bogu plačilo! Slovenski vojaki iz Svetovne vojne / zbrani na tem svetem kraju / 31. VIII. 1924.«

Osebni spomini sodobnikov niso bili pomembni samo zanje in za njihove bližnje, predstavljeni na javnih spominskih slovesnostih, na katerih so se vojni veterani zbirali ob posebnih datumih ali odkritjih spomenikov padlim vojakom, postajali so del kolektivnega spomina. To se pravi, da so sooblikovali spominske slovesnosti, kar pa jim je dalo politični pomen. Zveza slovenskih vojakov, kot so njeni ustanovniki radi poudarjali, je bila ustanovljena zaradi ohranjanja spominov na vojne izkušnje nekdanjih vojakov, tedaj kot nepolitična organizacija. Vendar si je organizirano in aktivno prizadevala obujati spomin na teme, za katere so pričakovali ugoden odmev ne le pri veteranih vojne, temveč tudi pri širšem krogu političnega telesa. Nekdanji vojni kurat in katehet Francè Bonač, nadvse agilni »tajnik in duša « Zveze slovenskih vojakov, je bil slavnostni govornik na številnih spominskih svečanostih in odkritjih spomenikov padlim vojakom širom Dravske banovine. V svojih govorih se je zavzemal za pravico do »dostojnega 
groba in primernega spomina « za padle vojake, pokopane $\mathrm{v} \gg$ slovenski grudi «, ne glede na njihovo narodnost (Bonač 1929: 407-8). Pri tem se je pogosto skliceval na svetopisemske primere, kot je zgodba o Savlovi stranski ženi Resfi:

V drugih bukvah kraljev beremo, da se je bil kralj Savel silno zameril Gabaoncem in jih je kljub dani besedi hotel pokončati z ognjem in mečem. Zavladala je v deželi Izraelovi lakota in trajala tri leta zaporedoma, dokler ni bilo Davidu, Savlovemu nasledniku, razodeto, da bo prenehala takoj, čim bo kruto razžaljenim Gabaoncem v polni meri zadoščeno. Oni so pa zahtevali kri Savlovih potomcev in kralj jim je dal sedem mož izmed Savlovih sinov in bili so križani na gori pred Gospodom. Resfa, njihova mati, pa je vzela žimnato oblačilo in si ga je razgrnila na skali in ni pustila, da bi jih bile ptice raztrgale podnevu ali zveri ponoči, dokler niso bili vsi dostojno pokopani ob kosteh Savla in Jonatana. Tako sveto pismo.

Kot je ta Resfa bdela in čuvala nad ubogimi trupli, na križ ji razpetih otrok, tako čuva Zveza slovenskih bojevnikov grobove padlih tovarišev in vzpodbuja naše ljudstvo, da ne pozablja svojih sinov, marveč da sleherna vasica postavi vsaj skromno ploščo njihovemu spominu in zanje moli ter se pokloni njihovi požrtvovalnosti, ljubezni in zvestobi do nas. (Bonač 1929: 407)

Bonač je dosledno poudarjal nepolitičnost združenja bojevnikov, vendar se kljub temu v svojih slavnostnih govorih nikakor ni izogibal žgočih političnih tem. Večkrat je povedal, da slovensko ljudstvo

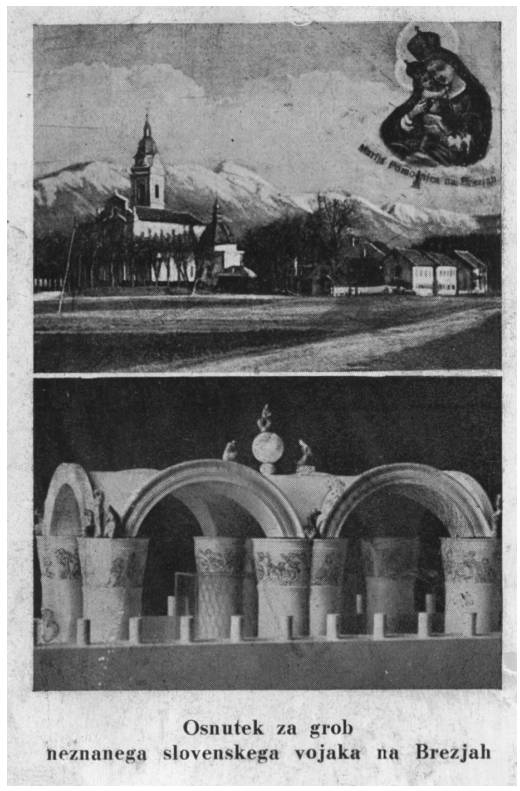

Slika 5: Osnutek groba neznanega vojaka na Brezjah (iz zbirke avtorja). 
ljubi »svojo zemljo «, zato zahteva, da jo ljubijo tudi voditelji države s tem, da jim lajšajo »težka davčna bremena in jih vračajo celokupnemu ljudstvu v državi brez razlike «; da ne puščajo v nemar »svojih invalidov, ki so doprinesli vse domovini na oltar «. To so bile, seveda, povsem očitno politične zahteve. Take narave je bilo tudi njegovo zavračanje tistih, ki so izražali dvome v patriotizem bojevnikov. Tem dvomljivcem je Bonač vračal očitek » avstrijakantstva « $\mathrm{z}$ očitkom »bizantinizma « in »klečeplastva «. Njegova molitev za »padle heroje « na shodu slovenskih vojakov na Brezjah leta 1925 pa je bil že povsem nedvoumen korak v smeri revizije zgodovine (Nepodpisano 1925d: 377).

Združenje bojevnikov je po slovenskih župnijah sprožilo živahno gibanje za vidno počastitev spomina padlih vojakov. Za svojce so bili nadomestilo za daljni grob, da so pred njim opravljali molitve za padle drage, župnijam pa neme, a trajne priče vojnih grozot. Število spominskih znamenj z vklesanimi imeni padlih, postavljenih ob cerkvah ali na pokopališčih, se je hitro povečevalo, prav tako število spomenikov; v desetih letih skorajda ni bilo več župnije brez njega (Nepodpisano 1935c: 1). Čeprav je vse to potekalo daleč od državnega središča in pod plaščem nerazumljivega jezika, so dogajanje opazili tudi v Beogradu. Beograjska Politika se je konec leta 1925 nejevoljno obregnila ob dogajanje:

»Ilustrovani Slovenec «, organ g. Korošca, stalno donosi slike spomenika koji se u Slovenačkoj dižu »palim vojakom « na bivšem italijanskom frontu. Poznato je da se ti spomenici otkrivaju sa poštom i uz učešće lokalnih i vatrogasnih vlasti.

Nemamo ništa protiv toga što porodice poginulih koji su izgubili ludu glavu - po nesreći, nevolji ili nesvesnosti - održavaju iz pieteta njihove grobove, ali zbunjeni smo kako da kvalifikujemo ove učestale svečane manifestacije koje imaju da odaju čast i da veličaju one koji su se borili protiv opšte savezničke i jugoslovenske stvari, za račun Karla Habsburga. Jer jasno je i neosporivo da su se »pali voja$\mathrm{ki} \ll$ borili protiv oslobođenja ove zemlje - možda preko svoje volje, ili možda i ne znajući šta to znači.

Neka braća Slovenci veruju da će svi Srbi bez razlike da vrisnu, ako se neko usudi - u istom duhu ideja - da diže spomenik srpskom renegatu feldmaršalu Borojeviću, komandantu austrijskih trupa na Soči. ${ }^{5}$ (Z. 1925: 5) de Bojna je bil na seji ljubljanskega občinskega sveta dne 6. avgusta 1916 na predlog župana Tavčarja »z velikim navdušenjem《izvoljen za častnega meščana in vpisan $\mathrm{v} \gg$ zlato knjigo najbolj zaslužnih mož slovenske domovine«. Pred njim je Ljubljana izkazala to čast le maršalu Radeckemu, admiralu Tegetthoffu in osvojitelju Bosne, generalu Filipoviću (Nepodpisano 1916c: 5-6). Po koncu vojne se je odnos do poveljnika primorske armade spremenil. Ljubljanski občinski svet je na svoji seji, dne 24. junija 1919, ki jo je vodil župan Ivan Tavčar, sklenil nekdanjega generala avstro- 
Politikine pomisleke je glavni odbor Zveze slovenskih vojakov v Slovencu zavrnil kot $\gg$ neosnovani napad «. Pri tem se je skliceval na to, da imajo po različnih državah padli vojaki, tudi sovražnih vojsk, urejene grobove, vključno z Nemci, ki so padli v naskoku na Beograd. Zato tudi Slovenci ne morejo molčati in pljuniti $\gg$ na kosti svojih bratov in sinov «, ki so padli na goriških in primorskih tleh, kjer so branili »našo zemljo $\ll$. Tem »junakom «, je zapisal glavni odbor Zveze slovenskih vojakov, kakor tudi padlim pri uporih tedanjih slovenskih polkov (Judenburg in Codroipo), »ki so do dna izpili kupo trpljenja «, je hvaležni slovenski narod nameraval postaviti spomenik v vsaki gorski vasi, ter sklenil, da upajo, da jih pri tem »niti z najmanjšo kretnjo ne bodo ovirali bratje Srbi, ki znajo ceniti svete kosti padlih borcev « (Glavni odbor ZSV 1925: 2).

\section{KRANJSKI JANEZI}

Upodabljanje vojakov v uniformah na spomenikih je bilo v nacionalni državi naroda obremenjeno s posebno hipoteko, saj je bila avstro-ogrska vojska tista, ki je napadla Srbijo in tam pustila za seboj ogromno človeških žrtev kot tudi strahotno razdejanje. V Dravski banovini so bili tako zasnovani spomeniki precej redkeje posejani, a nekaj jih je vendarle bilo. Prvega od njih, tako imenovanega Kranjskega Janeza, so postavili na ljubljanskem pokopališču Sv. Križa, vendar ne v spomin na bojišču padlim vojakom, temveč v spomin judenburškim žrtvam, ki bi morali na fronto, pa so se 12. maja 1918 uprli z geslom »Fantje, domov! « in bili zato ustreljeni štiri dni pozneje (Nepodpisano 1923a: 277). Kranjskega Janeza so namestili na kockast podstavek iz belega kamna s črnimi napisnimi ploščami med grobovi judenburških upornikov (Anton Hafner, Alojzij Rogelj, Alojzij Štefančič, Karel Možina in Jozo Dautović, poleg njih pa še posmrtne ostanke preporodovca Ivana Endlicherja, ki je umrl v zaporih v Grazu 15. septembra 1915 za svoje jugoslovanske ideale), okoli pa so bili še drugi vojaški grobovi (Nepodpisano 1923a: 277; Čopič 1987: 168-69). Na podnožju so

ogrske armade črtati iz seznama častnih meščanov (Nepodpisano 1919: 3). Boroevićev apel na čustvo pravičnosti »vseh merodajnih činiteljev v kraljestvu $\mathrm{SHS} \ll$, da je med vojno Jugoslovanom, »katerih zvest sin sem bil vsikdar in bom ostal vedno«, delal samo čast in da mu naj zato dajo »javno in tudi prebivalstvu umljivo zadoščenje « in tako izpodbijejo tla »mnogo razširjenemu prepričanju, da smo Jugoslovani nehvaležen narod « (Nepodpisano 1916c: 5), je ostal neuslišan. Nove oblasti so mu prepovedale vrnitev v domovino (Nepodpisano 1923b: 1). 
vklesali napis: »Vsem, ki so prelili kri in dali dušo v borbi zoper nasilje nam za svobodo.« Nekaj let po nastanku kipa pa v spremenjenih okoliščinah sodobnike tedaj še vedno edini kip na vojaških grobovih v Dravski banovini ni več spominjal na neomajno herojstvo Kranjskega Janeza. Pogled na kip iz novega zornega kota jim je zdaj vzbujal vtis, da se nekdanji zvesti avstrijski vojak ves zamišljen sprašuje: »Ali je tega treba? Ali je svet pravico pokopal? « (Nepodpisano 1923a: 277)

Po mednarodnih dogovorih bi za ljubljansko vojaško pokopališče morala skrbeti jugoslovanska država, vendar ne država ne ljubljanska občina svojih obveznosti nista izpolnili (Bonač 1932: 3). Leseni križi na zanemarjenih grobovih so strohneli, napisi z imeni pokojnikov zbledeli, grobove pa je obrastel plevel; v nasprotju s tem so bili italijanski vojaški grobovi na istem pokopališču skrbno vzdrževani. $\mathrm{Na}$ pobudo Zveze slovenskih vojakov je Plečnik izdelal »krasen načrt « za mavzolej, »ki bi stal v primeri z ureditvijo vojaških pokopališč drugih držav prav neznatno vsoto «, a država ni imela denarja, da bi »vsaj s tem pokazala hvaležnost tistim, ki so žrtvovali svojo kri za temelje Jugoslavije « (Vertin 1931: 5).

Plečnik si je zamislil »veličastno metropolo smrti«, kjer bi našlo dostojno počivališče kakšnih 9000 mož. Osrčje Plečnikove metropole smrti naj bi tvoril mogočen troglavi kopec, ki bi predstavljal s kamniškimi planinami v ozadju »iz srca do srca govoreč pomnik, da bi se človeštvo streznilo, spametovalo in spoznalo, da mu od krvavega obračunavanja preti le pogin, obup in smrt «. Srednji betonski steber bi bil visok devet metrov, stranska pa po šest. Vrh kopcev je predvidel tri križe, »ki bi bili klicarji k miru, spravi in edinosti«. Temelje za kopce naj bi izkopali tako, da obstoječih grobov ne bi poškodovali, le iz raznih krajev ostalega pokopališča bi sem prenesli kosti kakor tudi z Barja in drugih krajev. Za grobove »najodličnejših žrtev « (judenburške žrtve in koroški legionarji) je arhitekt predvidel lepše križce, majhne spomenike, ki so že stali, kakor tudi one, ki bi jih morda želeli postaviti svojci padlih ali konzulat te ali one države. $\mathrm{V}$ ta kompleks bi bil vključen tudi Kranjski Janez, »ta odlični spomenik našega nepoznanega slovenskega vojaka «. Pod srednjim troglavim kopcem bi bila mogočna odprtina na obe strani (» predor svetlobe «), kjer bi gorela »večna luč « in kjer bi ljudje prižigali svečke, lučke in podobno. $\mathrm{Na}$ vzhodni strani bi nekoč pozneje nastal manjši mavzolej, nekak »narodni panteon odličnih mož bojevnikov, ki so si stekli prav posebne zasluge za domačo grudo «. Katehet Bonač je zapisal, da bi bilo to vzorno urejeno pokopališče in dostojen spomenik mesta Ljubljane, na katerega bi s ponosom zrla država, banovina, zlasti pa mesto (Bonač 1932: 2-3). 
A tudi Plečnikov načrt je ostal neuresničen. Namesto tega so sredi decembra 1939 slovesno odkrili kostnico, narejeno po načrtih Eda Ravnikarja. Vanjo so prenesli posmrtne ostanke 5.258 pripadnikov avstro-ogrske vojske, srbskih, ruskih in romunskih vojnih ujetnikov, judenburških upornikov, koroških borcev ter preporodovcev. Kostnico je krasil kip Kranjskega Janeza, narejenega med vojno v kasarni v Judenburgu. Osnutek zanj je napravil slikar Ivan Vaupotič, predstavlja pa navadnega pehotnega vojaka na kamnitem podstavku s puško ob nogi, čepico v roki in patronskimi torbicami okoli pasu; glavo ima povešeno, zamišljeno, tako kot pri molitvi. Za spomenik so nabirali prostovoljne prispevke med vojaki (Nepodpisano 1916b: 5). Izklesal ga je enoletni prostovoljec kipar Svitoslav Peruzzi, vendar ga ni dokončal, ker je bil prej odpuščen iz vojaške službe. Dokončal ga je enoletni prostovoljec kipar Lojze Dolinar (Nepodpisano 1916a: 4; Orešan 1917: 115; Dobida 1923: 9; Čopič 1987: 168-69). Kiparjev prijatelj je leta 1917 objavil članek o nastajanju kipa Kranjskega Janeza in umetnikovem umevanju slave kranjskega pešpolka »Cesarjevič «:

\begin{abstract}
Ako opazujemo spomenik 17. pešpolka, se nam zdi, da premišlja odkriti vojak s puško ob sebi, v neomejeni zvestobi do cesarja in domovine, koliko je že storil njegov polk za državo, koliko slave je pridobil $\mathrm{z}$ mečem, $\mathrm{s}$ puško $\mathrm{v}$ roki. Vojak premišlja prošle in bodoče dni slave in zmage, spominja se junakov, ki so jo, ki jo bodo dosegli s tem, da so žrtvovali vse najdražje na altar domovinski - svoje živjenje. Ni žalosten zaradi tega, marveč miren, resen, ponosen, kakor da ponavlja: »Tukaj sem, tukaj ostanem jaz, in moja slava ne mine, dokler bo dihal moj rod po kranjskih hribih in dolinah, po planinah in Ljubljanskem polju - celo tam pod črnim Krimom na Barju.«Vsaka žilica na ustvarjenem junaku diha življenje, ponos in samosvest. Takšen je Kranjski, slovenski vojak - junak! (Orešan 1917: 115-16).
\end{abstract}

Po prvotni zamisli naj bi kip Kranjskega Janeza postavili v Ljubljani kot spomenik slovenskemu junaštvu in zvestobi do Avstrije (Nepodpisano 1916b: 5). Na začetku pomladi 1917 je poveljstvo nadomestnega bataljona c. in kr. pešpolka »Cesarjevič « št. 17 poslalo dopis ljubljanskemu županu, v katerem sporoča, da namerava sporazumno $s$ polkovim poveljstvom v Ljubljani postaviti spomenik junakov. Nadomestno bataljonsko poveljstvo je pisno zaprosilo ljubljanski občinski svet, naj zanj določi prostor in začne s temeljnimi deli. Župan Tavčar je dopis pospremil s kratkim komentarjem: »Samoobsebi umevno je, da bo Ljubljana pozdravila to misel.« Po županovem mnenju bi bil primeren prostor za spomenik park na trgu Tabor ali pa pred šentpetrsko vojašnico (Nepodpisano 1917: 1-2). Vendar so kip postavili šele leta 1923, ko so v Ljubljano pripeljali posmrtne ostanke judenburških žrtev. Odbor za prenos kosti Ivana Endlicherja in Odbor za prenos kosti judenburških 
žrtev sta konec maja 1923 nagovorila $\gg$ Svobodni narod «, naj se pokloni kostem junakov in mučenikov, ki bodo večno njegova svetinja in njegove zemlje najdragocenejša last: »Poginili so zate, narod, in tvoje odrešenje je bilo njihov krvavo zapečateni testament. $\mathrm{Z}$ mučeniško svojo smrtjo so izpričali pred svetom in pred zgodovino tvojo voljo, da si vladaš sam; poslednja njihova misel je plamenela nad teboj, ko si stopil iz teme suženjstva v beli jugoslovenski dan Svobode« (Odbora 1923: 1).

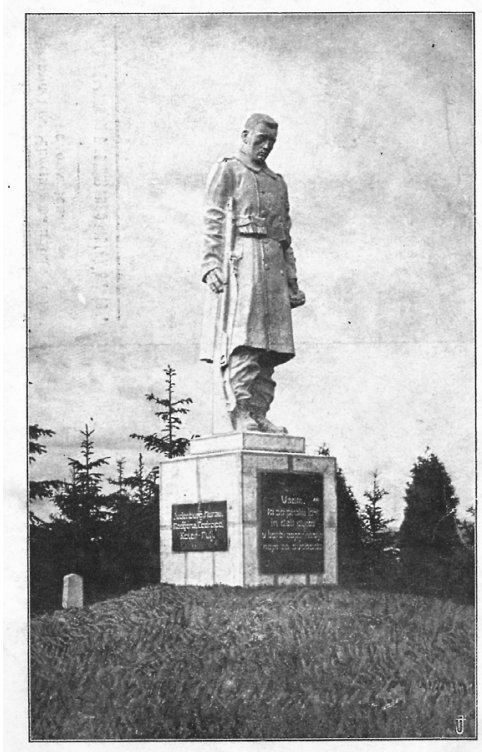

Slika 6: Kranjski Janez na ljubljanskih Žalah (iz zbirke avtorja).

Nekaj let za Ljubljano so Kranjskega Janeza postavili tudi na Dovjem. Tam so v nedeljo, 24. maja 1925, slovesno odkrili spomenik $\mathrm{v}$ vojni padlim in umrlim vojakom iz občine Dovje-Mojstrana $\gg v$ topel spomin, poznejšim rodovom pa $\mathrm{v}$ nem opomin « (Nepodpisano 1938g: 3). Spomenik je blagoslovil duhovni svetnik Jakob Aljaž ob asistenci druge duhovščine, slavnostni govornik pa je bil vikar Bonač (Nepodpisano 1925a: 7; 1925b: 3; 1925c: 4). Spomenik je bil zgrajen na pobudo pripravljalnega odbora, v katerem so bili člani različnih svetovnih nazorov in političnih prepričanj. Ob premišljevanju, kaj naj bi predstavljal kip, so se odločili za podobo vojaka 17. slovenskega pešpolka v tedanji uniformi polka. Odbor je zastopal stališče, da »zgodovine pač ni mogoče potvarjati«, spomenik naj bi bil »dokument časa, žalosten spomin na še bolj žalostno preteklost, ko so bili slovenski fantje in možje prisiljeni sodelovati v svetovnem pokolju « (Nepodpisano 1938g: 3). 


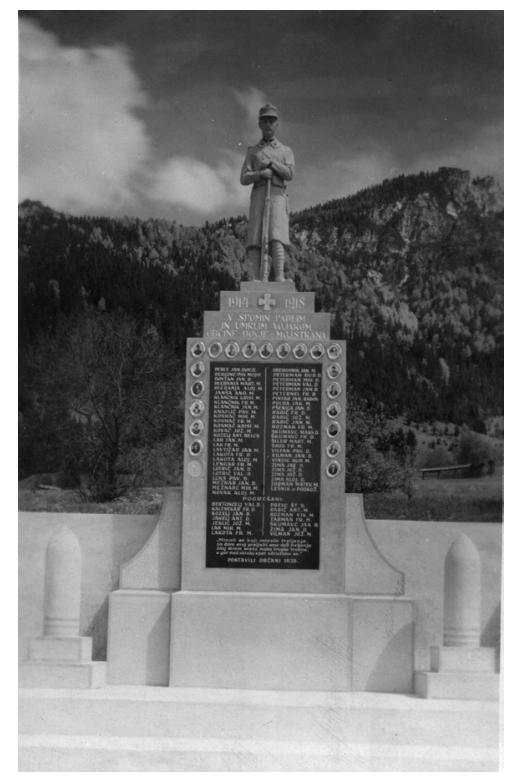

Slika 7: Kranjski Janez v Dovjem (iz zbirke avtorja).

A vsi očitno niso delili tega mnenja. Neke noči so spomenik na Dovjem podrli, ker je »baje predstavljal vojaka v preveč avstrijski uniformi, kakor pravijo, in so zato nekateri že dalje časa ugovarjali« (Nepodpisano 1938f: 8). Z lato, izruvano iz bližnjega kozolca, so kip s podstavkom vrgli na tla in odnesli njegovo glavo. Marmorna plošča z vklesanimi imeni okoli 60 padlih in pogrešanih vojakov je ostala nepoškodovana. »Žalosten je zdaj pogled na razdejani spomenik - nemo pričo trpljenja slovenskih fantov in mož, ki so se morali boriti za tuje samogoltnike in zatiralce našega naroda «, je poročal Slovenec. »In vprav zato je imel spomenik svojstven zgodovinski pomen in namen « (Nepodpisano 1938g: 3).

\section{POLITIKA NARODNE SLOGE}

V procesu ohranjanja kolektivnega spomina so se spomini posameznikov na njihove osebne izkušnje vse bolj prepletali z interpretacijami smisla vélike vojne, kakor so ga predstavljali šolski učbeniki in drugi zainteresirani deležniki. Nekateri vidiki vojne so se pri tem umikali v ozadje, medtem ko so drugi pridobivali vse večji simbolični pomen (Ziemann 2013: 1). Spominjanje na vojne strahote je po véliki vojni dobilo svoj najbolj značilen izraz v grobnici neznanega vojaka. Z njo 
so želeli v otipljivi in individualizirani obliki izraziti spoštovanje ogromnemu številu padlih vojakov, od katerih trupla so bila v številnih primerih iznakažena do neprepoznavnosti ali pa so celo izginili brez sledu. Grobnica neznanega vojaka je simbolizirala vse vojne žrtve določenega naroda in izražala priznanje za njihova junaštva, hkrati pa je preživelim omogočala žalovati za vsakim posameznim padlim vojakom. Njihovo središčno mesto $v$ socialnem spominu je poudarjala lokacija $\mathrm{v}$ glavnih mestih držav, udeleženk vojne. Prvi grobnici neznanim vojakom so namreč postavili v Parizu in Londonu leta 1920, naslednje leto v Rimu in Washingtonu, še leto pozneje v Bruslju, Pragi in Beogradu, leta 1923 v Bukarešti in na Dunaju. Spominske svečanosti so bile močno podobne druga drugi, prisostvovali so jim vodilni civilni in vojaški dostojanstveniki, vojni veterani ter množice državljanov (Mosse 1990: 80-93; Van Ypersele 2010: 579-80).

Pred véliko vojno so bili heroji, katerih slavna dela so hoteli okameniti v spominu za prihodnje generacije, vojskovodje; navadni vojaki so bili prepuščeni pozabi (Mosse 1975: 37, 47; 1990: 99; Borg 1991: 104; Gillis 1994: 9; Winter 2006: 281). Vojni pretres v letih od 1914 do 1918 je imel za posledico, da je glavne junake kolektivnega spomina sčasoma zamenjal »neznani vojak «, to je »vojak-prostak «, ki je nosil največji del teže in nevarnosti »najtežje vojne, ki se je kdaj slišalo o njej « (Strobl 1915: 1). Strahotna bilanca vojne, ki ni imela primere ne $\mathrm{v}$ izkušnji sodobnikov ne $\mathrm{v}$ zgodovinskih kronikah, je odprla in ugladila pot demokratični misli, da naj bo narod sam svoje sreče ali nesreče kovač, da naj si sam naloži to, kar more nositi, češ: »Kdor ima pravico trpeti, pravico žrtvovati, imej tudi pravico sam odločevati o svojih žrtvah in svojem trpljenju « (Neznan 1919: 91).

Uspeh v postavljanju spominskih obeležij in spomenikov je leta 1927 spodbudil tudi nekdanje slovenske bojevnike k razmišljanju, da tudi Slovenci ne morejo zaostajati za velikimi narodi (Glavni odbor ZSV 1927: 3). Zaradi politične delikatnosti zamisli o skupni grobnici oziroma »slovenskem bojevniškem panteonu « (Nepodpisano 1935d: 2) je njeno uresničevanje potekalo dokaj počasi. Pri izbiri lokacije za skupno grobnico so dali prednost Brezjam pred Ljubljano. Odločilen za izbiro je bil politični premislek, saj je bilo spominske svečanosti na Brezjah laže predstavljati kot apolitičen, zgolj versko-pietetni dogodek. Brezje so bile romarska pot, ki ni ločila Slovencev po prirodnih in državnih mejah (Častni odbor 1937: 1). Spominske svečanosti z velikim številom udeležencev v Ljubljani bi hitro dobile zunanjo podobo politične manifestacije, ki bi vzbudila povečano pozornost državnih oblasti. Lahko bi jo prepovedale ali celo $s$ silo preprečile. 
Arhitekt Valentinčič je izdelal načrt, ki je predvideval na prostoru pred cerkvijo park s spomeniki slovenskih zaslužnih mož in Marijinih častilcev, v njem naj bi stal tudi grob neznanega slovenskega vojaka. Spomenik naj bi ohranjal spomin na vseslovenske vojake, padle v véliki vojni, poznejšim rodovom pa pričal o »velikih žrtvah, ki jih je prinesel slovenski narod za svojo svobodo, dasi se je bojeval za tujo korist «. V parku naj bi se dvigal steber, iz katerega bi vrela voda, kot simbol vrelca ljubezni Marijinega srca, $s$ kipom Marije Pomočnice na vrhu stebra. Izvedbo načrta je prevzela Zveza bojevnikov, da bi se tako oddolžila umrlim vojakom iz svetovne vojne in okrepila vero v Marijino pomoč. $\mathrm{Za}$ denarne prispevke so se bojevniki obrnili na vseslovenske župne urade, občine, denarne zavode in posameznike, ki naj bi s tem svetu pokazali, da so Slovenci res »Marijin narod « (Častni odbor 1937: 1).

Izvajalci akcije za postavitev spomenika Neznanega slovenskega vojaka so pojasnjevali, da spomenikov ne postavljajo v čast kakšni državi ali narodu, še manj pa kakšni politiki. Če bi slovenski vojni spomeniki slavili vojne cilje katere koli države, bi bilo najbolje, da bi podrli vse vojne spomenike po vsem svetu. Pomen spomenikov padlim je zunaj vsake državne ali nacionalne politike, saj kulturni narodi postavljajo spomenike padlim sovražnikovim vojakom. Šlo naj bi tedaj zgolj za izraz pietete do žrtve vojne, saj so na bojnih poljih obležali bivši sovražniki in prijatelji, vsi pa si enako zaslužijo pobožen spomin. »Ne gre za to, kdo je imel prav in kdo ne. Kdo pa to ve? Borili so se, zvesti svoji vojaški prisegi, zvesti svoji domovini in za to zaslužijo vsi brez izjeme, naj bodo tu ali tam, spoštovanje in slavo « (Nepodpisano 1938d: 25).

Grob neznanega slovenskega vojaka na Brezjah naj bi imel pomembno vlogo v oblikovanju slovenske narodne zavesti kot ponosna priča za prihodnje rodove, »da se je slovenski narod zavedal svoje samobitnosti, cenil žrtve za svojo svobodo in pokazal veliko spoštovanje do svojih očetov in bratov, ki so pretrpeli strašno gorje svetovne vojne « (Nepodpisano 1938c: 1). Zato je bilo načrtovano, da bo vsaka slovenska župnija imela poseben prostor, kjer bodo z zlatimi črkami vklesana imena padlih in umrlih v svetovni vojni. Župnije bi bile razvrščene po abecednem redu, imena padlih pa po prijavah posameznih župnij. Ker je bila izvedba celotnega načrta povezana $\mathrm{z}$ velikimi stroški, so pričakovali, da bodo svojci prispevali 300 dinarjev za vsako ime, vklesano na steber ob spomeniku (Nepodpisano 1938b: 8; 1938c: 1; 1938d: 25). Zveza bojevnikov je v letih 1938, 1939 in 1940 izvedla več prireditev in zbiralnih akcij, na katerih so zbrali potrebna sredstva za dostojni spomenik padlim vojakom pri Materi božji na Brezjah (Nepodpisano 1938a: 1; 1939a: 2; 1940b: 13). 
Zadnjo nedeljo v avgustu 1937 so ob prisotnosti najvišjih zastopnikov cerkvenih in posvetnih oblasti ter rekordnem obisku $\gg$ božjepotnikov « (Nepodpisano 1937a: 2) blagoslovili temeljni kamen za spomenik neznanemu slovenskemu vojaku, v katerega so vzidali listino, ki jo je prečital predsednik Zveze bojevnikov Mirko Ratej. Temeljni kamen je blagoslovil knezoškof Gregorij Rožman, bojevniški zbor je zapel žalostinko Usliši nas, Gospod (Nepodpisano 1937b: 6-7; 1937c: 11; 1937d: 1; 1937f: 1; 1937g: 6). Takoj za tem je bilo zborovanje, ki ga je začel Ratej s pozdravom odposlancu kralja in kneza-namestnika Pavla podpolkovnika Pavliča. Množica je navdušeno vzklikala kralju, knezu-namestniku in kraljevskemu domu, godba pa je zaigrala državno himno. Nato je imel slavnostni govor ban Marko Natlačen, pokrovitelj slavnosti. Spomenik slovenskemu vojaku oziroma slovenskim žrtvam svetovne vojne, je dejal, na dostojen način izkazuje hvaležnost tisočem slovenskih vojakov, ki so »s svojimi žrtvami, s svojo krvjo in s svojim življenjem odkupili osvobojenje našemu narodu «. Spomenik slovenskemu vojaku naj bi v ljudeh budil in gojil »čisti in neusahljivi ogenj ljubezni do naše zemlje in do naše države! « (Nepodpisano 1937e: 1).

Dela za izgradnjo spomenika so potekala še leta 1940, ko si je pred bojevniškim praznikom delovišče ogledal slovenski »narodni voditelj«, prosvetni minister in predsednik senata Anton Korošec (Nepodpisano 1940a: 6-7). Zveza bojevnikov je vsako leto skrbela, da so se 1 . novembra širom Dravske banovine opravile žalne svečanosti na pokopališčih, pri spomenikih in spominskih ploščah $\mathrm{v}$ počastitev spomina padlih in umrlih bojnih tovarišev; nazadnje se je to zgodilo leta 1940. Sredi novembra 1940 je Zveza bojevnikov priredila dvoje skupnih potovanj na grob kralja Aleksandra v Oplencu (Nepodpisano 1940b: 13). Izbruh druge svetovne vojne je prekinil prizadevanja tako za postavljanje spominskih znamenj kot žalnih svečanosti, $\mathrm{v}$ pozabo je padel celo načrt za spomenik neznanemu slovenskemu vojaku. Eno zadnjih dejanj nekdanjih bojevnikov je bil spomladanski obisk pri šefu pokrajinske uprave generalu Leonu Rupniku, ko so mu čestitali k polletnici prevzema oblasti v Ljubljanski provinci in izjavili pripravljenost za boj proti komunistom (Nepodpisano 1944: 2).

MRTVI KAMNI V VLOGI ŽIVIH PRIDIGARJEV, TOLAŽNIKOV IN PREROKOV

Neposredno po koncu vojne so po vseh vaseh in mestih v Srbiji družine padlih vojakov začele množično postavljati spomenike, ob katerih so se 
zbirali žalujoči člani družine, sorodniki in znanci. Sčasoma so sprejeli izgubo svojih dragih, ta je postala del osebnih in družinskih identitet. Tedaj so aktivnosti pri ohranjanju spomina na padle vojake začeli prevzemati lokalni odbori za postavljanje spomenika. Ti so posamične iniciative povezovali z državno usmerjenimi predlogi in poskusi oblikovanja kolektivnega spominjanja padlih skozi »njihovo nacionalizacijo, tj. umeščanjem v identitetne okvire nacije « (Manojlović Pintar 2014: 134). Po letu 1918 so v srbskih krajih postavili številne javne spomenike $\mathrm{z}$ upodobitvami vojakov $\mathrm{v}$ uniformah zmagovite srbske vojske, praviloma obutih v opanke in šsajkačo na glavi.

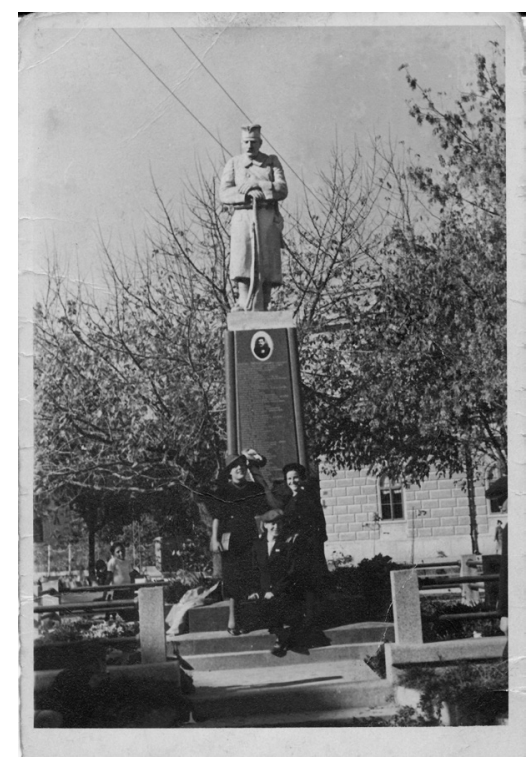

Slika 8: Spomenik srbskim vojakom, padlim za osvoboditev in združitev 1912-1918, Smederevo.

Spomenike padlim vojakom so nekako od sredine dvajsetih let prejšnjega stoletja postavljali po vaseh in trgih širom Dravske banovine. Prvo slovensko mesto, ki je postavilo spomenik »domačim in tujim junakom «, pokopanim na tamkajšnjem pokopališču, ter ga prevzelo v oskrbo in last, je bila Škofja Loka. Škofjeloška podružnica Zveze slovenskih vojakov je v nedeljo, 7. oktobra 1928, priredila veliko žalno svečanost ob odkritju spomenika padlim vojakom različnih narodnosti. V času, ko so za spomenike zaslužnim za domovino v Beogradu in drugje po srbskem delu države odobravali kredite, za spomenike »palim vojakom « pa ne (glej npr. Nepodpisano 1928c: 3), je čustva postavljalcev škofjeloškega spomenika zgovorno sporočala že sama oblika spomenika; ta je bila » izrazito slovenska « (Nepodpisano 1928a: 2). Spomenik predstavlja »trpečo mater Slovenijo v slovenski 
narodni noši z avbo, žalujočo za izgubljenimi sinovi in sočustvujočo $\mathrm{z}$ milijoni mater, ki objokujejo svoje padle sinove « (Nepodpisano 1928a: 2; 1928b: 9). Na podstavku so vklesane letnice 1914-1918 in imena 159 padlih vojakov iz Škofje Loke in okoliških vasi, pod njimi verzi Otona Župančiča in besede Tineta Debeljaka »V naši molitvi so spet vsi doma « (Nepodpisano 1928a: 2).

Spomeniki padlim vojakom in spominska znamenja so se na Slovenskem množili iz leta v leto, prav tako število žalnih svečanosti za padle vojake. Prireditve v organizaciji Zveze slovenskih vojakov, kakor tudi tiste, izvedene po prepovedi njenega delovanja, so govorile vse bolj jasen in razločen jezik politike, angažirane v boju proti centralizmu in za slovensko avtonomijo. Na prireditvah ni mogel govoriti kdor koli, temveč je bil govorniški oder dostopen samo vnaprej potrjenim govorcem, članom ali pristašem ene politične opcije (glej npr. Nepodpisano 1933b: 1; 1933c: 3; 1934d: 1-2; Spindler 1934: 2). Njihov jezik je bil pogosto skrajno radikalen, manjkalo ni niti žaljivk, uperjenih tudi zoper najvišje predstavnike državne oblasti (Nepodpisano 1933a: 1; 1936: 1). Minister Ivan Pucelj je o Zvezi bojevnikov izjavil, da je zašla na »stranpota «: »neki gospodje so jo zavedli na politično polje v namenu, da iz nje osnujejo politično stranko «. Po Pucljevem mnenju bi Zveza bojevnikov morala imeti en sam namen, namreč, da »slavi naše

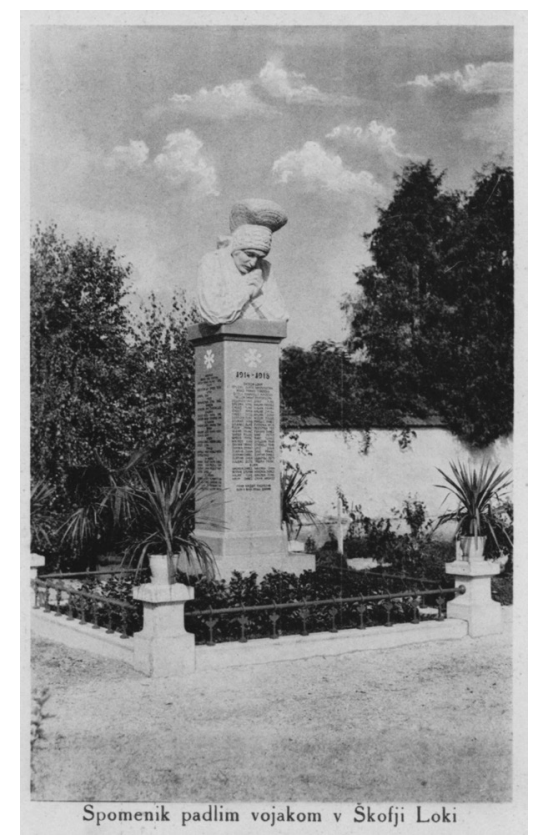

Slika 9: Spomenik padlim vojakom v Škofji Loki (iz zbirke avtorja). 
narodno osvobojenje «, zato bi se morala zavedati, da so se slovenski vojaki, ki so se borili v avstrijskih uniformah, »borili samo kot sužnji tuje države « (Nepodpisano 1933a: 1).

Politična motivacija svečanosti v čast padlim vojakom je prišla povsem očitno na plano sredi 1930-ih let, ko so začeli prirejati tako imenovane tabore slovenskega naroda. Prvi se je vršil v nedeljo, 11. avgusta 1935, v Komendi. Tabora se je udeležila večtisočglava množica, sodelovali so šolska mladina, gasilci, narodne noše in domžalska godba. Slavnostni govornik je bil ban Marko Natlačen, ki se ni obračal v preteklost, temveč je vse misli posvetil sedanjosti, predvsem odnosu med slovenstvom in jugoslovanstvom, kako $\gg$ mi pojmujemo jugoslovanski narod in jugoslovansko narodno edinstvo «. Po njegovem gledanju je bilo treba strogo ločiti pojem jugoslovanskega naroda v državnopravnem, političnem smislu od jugoslovanskega naroda $\mathrm{v}$ etičnem, kulturnem smislu. Vsi državljani Jugoslavije, je pojasnjeval Natlačen, vključno z Nemci in Madžari, tvorijo jugoslovanski narod v političnem smislu. V etničnem, kulturnem smislu pa so bili po banovem videnju Srbi, Hrvati in Slovenci »tri narodne edinice, ki ima vsaka svoje osobine, ki se morajo spoštovati in gojiti $\mathrm{v}$ jezikovnem, kulturnem ter $\mathrm{v}$ vsakem drugem pozitivnem pogledu, $\mathrm{v}$ uradovanju, $\mathrm{v}$ javnem življenju sploh, zlasti pa na šolskem polju, in to v okviru ideje višje jugoslovanske skupnosti «. Zato kakršna koli hegemonija enega naroda nad drugimi nikakor ni dopustna:

Ko smo se leta 1918. zedinili s Hrvati in Srbi v eno skupno državo, nismo tega storili zato, da bi se odrekli svojemu slovenskemu jeziku in svojim slovenskim osobinam: storili smo to, da bi v bratski skupnosti s Hrvati in Srbi postali močnejši, da bi slovenstvo vsestransko ojačili. Tudi danes stopamo $\mathrm{v}$ ožjo politično zvezo $\mathrm{z}$ namenom in $\mathrm{v}$ prepričanju, da bomo s tem uspešno služili tudi slovenstvu. (Nepodpisano 1935b: 1-2)

Število spomenikov in spominskih obeležij je tudi v Dravski banovini naraščalo iz leta v leto. Kot je nazorno prikazal Vito Hazler (glej v tej knjigi), se je njihovo število močno približalo številu štiristo. Sčasoma so se med njimi pojavile tudi figuralne upodobitve vojakov $\mathrm{v}$ uniformah; v skladu z zgodovinskimi dejstvi, kot se je glasilo pojasnilo, so bili na slovenskem ozemlju odeti v avstrijske uniforme. Med drugim so tak spomenik postavili svojim dragim, ki so padli v véliki vojni, tudi trebanjski župljani. Na dan slovesnega odkritja spomenika so bile Trebnje okrašene z zastavami. Dopoldne je potekala spominska maša za vse padle in v vojni umrle trebanjske župljane. Med mašo je imel v nabito polni župni cerkvi govor nekdanji vojni kurat France Bonač, ki je $s$ svojimi izvajanji ganil Trebanjce $\gg$ do solz«. Poudarjal 
je, da je docela v duhu slovenskega ljudstva, da postavljajo primerne spomenike vojnim žrtvam in ob tej priliki zanje molijo. Kot je poročal Slovenec, je Bonač med drugim rekel, da je vse, kar prirejajo drugi narodi na grobovih neznanih junakov, »lepo, častitljivo «, a slovenska mati se ni zadovoljila z željo, naj bo njenemu dragemu sinu zemljica lahka, temveč tudi moli »za mir in pokoj njegovi duši « (Nepodpisano 1933f: 1). Trebanjski spomenik je posvečen 98 trebanjskim župljanom in tudi s svojo veličastnostjo opozarja vsakogar na veliko žrtev, ki jo je prinesla trebanjska fara na žrtvenik svetovne vojne. Naslonjen je na steno župne cerkve, ki gleda na glavno cesto, in je visok nad 6 metrov. $\mathrm{Na}$ razvalinah bojišča stoji vojak v polni vojni opremi, ves skrušen in strt. Za njim pa stoji ob križu Kristus - Tolažnik in Pomočnik, ki ga dviga iz obupa. Ob strani sta postavljeni iz črnega granita izklesani veliki granati, na sredi podstavka pa je vzidana marmornata plošča z napisom » Junakom - naše domovine rojakom «. Ob straneh stojita še dve veliki vazi iz umetnega kamna, polni cvetja (Nepodpisano 1933d: 3; 1933e: 2; 1933f: 1; 1933g: 2; 1933i: 610; 1933j: 7). Kot je dejal v svojem govoru ob svečanem odkritju predsednik pripravljalnega odbora za postavitev spomenika dekan Tomažič, naj bi spomenik bodočim rodovom kazal strahote svetovne vojne in jih opozarjal na ljubezen do rodne zemlje. Hkrati naj bi bil opozorilo tistim, ki so si morda želeli

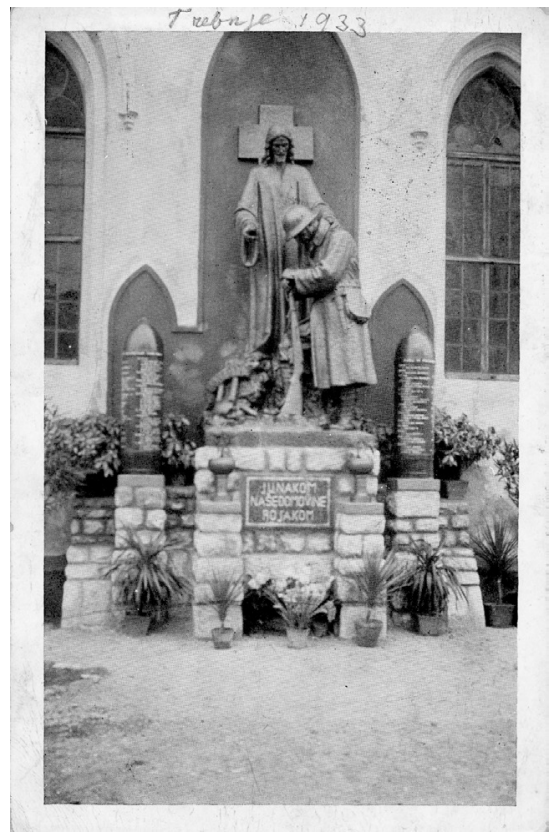

Slika 10: Spomenik » junakom naše domovine «, Trebnje. 
vojske ali prepira. Vsakogar pa naj bi učil ljubezni do križa, domovine in mladine (Nepodpisano 1933h: 3). A slavnostni govornik ni pojasnil, kako razumeti napis, ki pravi, da junak v (avstrijski) uniformi pooseblja domovino. Namreč, katero, avstrijsko ali jugoslovansko? Kakor koli že, postavljanje kamnitih vojakov v srbskih uniformah v enem delu nacionalne države in avstrijskih uniformah $\mathrm{v}$ drugem je po svoje sporočalo, da vojna teče naprej, čeprav je bila uradno končana 11 . novembra 1918.

Najsi se je resničnost vojnih let še tako razlikovala od črno-belih propagandističnih upodobitev, je ta ohranila svojo privlačnost skozi vse vojno obdobje, povojne krize in konflikti pa so ji še dolgo po koncu vojne dajali veliko življenjsko moč. Skupno življenje zmagovalcev in poražencev v skupni državi je predstavljalo tako rekoč nepremagljivo oviro pri oblikovanju skupnega kolektivnega spomina na véliko vojno kot ustanovni mit nove nacionalne države. Ena najpomembnejših nalog nacionalne države naroda s tremi imeni v komemoracijah za padlimi vojaki je bila v vzpostavljanju in ohranjanju »zamišljene skupnosti $\ll$, pa tudi njenih pripovedi in ritualov, ki omogočajo pripadnikom te skupnosti, da presegajo delitve znotraj skupnosti. A v skupni državi Jugoslovanov v največji meri prav zaradi delitve iz vojnih let nikoli niso uspeli oblikovati skupnega spomina na preteklost, ki bi njenih državljanov ne ločeval, temveč jih povezoval (Ashplant 2000: 263). Spominske podobe na vojna leta so bile vse tesneje povezane $\mathrm{z}$ različnimi gledanji na vzroke in posledice političnih in ekonomskih kriz, ki so pretresale skupno državo.

Vodilni srbski politiki, ki so pokrivali tudi levji delež oblastniških mest v skupni državi v časih krize, niso pozabili omenjati velikih srbskih žrtev za osvoboditev in ujedinjenje. Dejstvo, da je dunajska vlada mobilizirala $\gg 1.356 .000$ prebivalcev Hrvaške, Dalmacije, Slovenije in Bosne in Hercegovine « ter jih v avstro-ogrskih uniformah poslala na bojišča v Galiciji, Severni Italiji, Srbiji in Solunu (Protić 2009: 219), recimo, ni ostalo neopaženo; čeprav so tisti, ki so opozarjali nanj, prikladno pozabili navesti, da so vojake za avstro-ogrske enote mobilizirali tudi v Vojvodini. Prav tako ne, da so se ti bojevali v sklopu centralnih sil in da so v okupirani Srbiji storili $\gg$ neštevilne vojne zločine zlasti nad civili« in bi se zaradi tega po odločitvi velikih sil antante morali zagovarjati pred obličjem pravice. Tako imenovani Jugoslovani oziroma Hrvati naj bi večkrat brezuspešno poskušali dobiti zase status zavezniških enot $s$ silami antante, zato naj bi bil zanje edini izhod ujedinjenje s Srbijo. »Ideja integralnega jugoslovanstva jim je dobro služila. Za Hrvate in Slovence je bila lek, za Srbe - strup « (Protić 2009: 219). 
Jezikovna razlika in geografska odmaknjenost slovenskega ozemlja od središča države sta to sporočilo uspešno prikrivali. Toda postavljanje spomenikov in spominskih obeležij padlim vojakom na način, kot so ga izbrali v srbskem in slovenskem delu skupne države, je vodil $v$ oblikovanje ločenih spominov na vojna leta in z njimi povezanih razdiralnih posledic za obstoj skupnosti. Namreč, zgolj tisti spomini, ki so povezani v skupno pripoved, ki je splošno razširjena med državljani in jih ti tudi javno izražajo, imajo potencial za to, da zagotavljajo ustrezen politični povezovalni učinek (Ashplant, Dawson in Roper 2000: 20). Drugi »Jugoslovani « oziroma »Hrvati « so bili zaradi večje podobnosti jezika in geografske bližine bolj na očeh, zato je bila nanje tudi pogosteje uperjena ost kritike, ker so se med véliko vojno bojevali na sovražnikovi strani; to so večkrat komentirali tuji politiki bodisi z določenim namenom bodisi brez njega. Alex Dragnich navaja primer francoskega premierja Clemenceauja, ki je trdil, da nikoli ne bo pozabil, da so se »Hrvati « borili na sovražnikovi strani (Dragnich 1983: 60).

Za vojno resničnost je značilna črno-bela delitev sveta na Naše in Sovražnike, med katerimi je začrtana jasna ognjena linija. Propagandna mašinerija na obeh straneh fronte si prizadeva s poudarjanjem tistih dejstev, ki potrjujejo tako podobo sveta, in zamolčevanjem onih, ki jo kot tako problematizirajo. Življenje pa niti v času najhujših vojnih spopadov ne poteka po pravilu črno ali belo. Vendar črno-bele delitve sveta, uporabljane kot orodje za mobilizacijo za vojno, nikoli ne izgubijo svoje prepričljivosti. Delitev na zmagovalce »Srbe« in poražence $\gg$ Hrvate « se je zlasti v kriznih časih zlahka pretvorila v globok vir medsebojnih sumničenj in nezaupanja. V novi državi pa so se politične in ekonomske krize pojavljale redno in pogosto, tudi zaradi teh sumničenj in nezaupanja, zaradi česar je del politikov marljivo s prstom kazal nanje. Nekateri so prav te delitve predstavljali kot glavni vir vseh težav, s katerimi so se spopadali državljani skupne države. Znana angleška pisateljica Rebecca West, avtorica obsežnega potopisa o Jugoslaviji Črna ovca in sivi sokol (1942), recimo, je tolmačila sodobne probleme, s katerimi se je v letih pred drugo svetovno vojno spopadala Jugoslavija, z nezmožnostjo sožitja $\gg$ Srbov « in »Hrvatov« zaradi krvave vojne preteklosti. V njenem potopisu se »Konstantin «, kakor pisateljica imenuje srbskega pesnika Stanislava Vinaverja, ogorčeno spominja srbsko-hrvaških spopadov med preteklo vojno:

Počnejo strašne stvari in še nas silijo početi strašne stvari, ti Hrvati. Kadar Bog deluje prek Hrvatov, deluje grozno. Naj vam povem, kaj se je nekoč zgodilo v vojni. V Srbiji je bil hrib, za katerega smo se 
z avstrijskimi četami bojevali vso noč. Nekaj časa smo ga imeli mi, nekaj časa spet oni, na koncu pa smo ga dokončno osvojili: Ko so nas napadli, smo jim klicali, naj se predajo, a skozi noč so nam odgovarjali, »Cesarjeva vojska se nikoli ne preda «, in to v našem jeziku. Tako smo vedeli, da so bili naši bratje Hrvati, in zato, ker so bili naši bratje, smo vedeli, da mislijo resno, in tako so prišli nad nas, in morali smo jih ubiti, in vsi so zjutraj ležali mrtvi, vsi pa so bili naši bratje. (West 1942: I, 89)

Kot smo videli, so se na srbski fronti resnično bojevali številni jugoslovanski vojaki v avstro-ogrskih uniformah. Vendar to nikakor niso bili izključno Hrvati, temveč so bili med njimi tudi Bošnjaki in Slovenci, a, kar je pomembno, niti Srbov ni manjkalo. Vendar priučeni črno-belemu gledanju na svet iz vojne propagande, ki je ljudi delila na Naše in Sovražnike, so formule tolmačenja sveta iz vojnih let prenašali tudi v povojna leta miru: $v$ avstro-ogrskih enotah med vojno je epski pogled na dobljeno vojno videl med bojevniki izključno »Hrvate $\ll$. Vélika vojna se je potemtakem nadaljevala še v povojnih letih, in sicer tako na simbolni kot na verbalni ravni, vsekakor pa z močnim čustvenim angažmajem. Na to vnetljivo mešanico so streli v narodni skupščini 1928. leta prilili še človeško kri.

\section{CITIRANE REFERENCE}

A. L. 1934 Devica Marija v Polju; Bojevnik, 15. aprila, str. 3.

Adamic, Louis 1934 The Native's Return. An American Immigrant Visits Yugoslavia And Discovers His Old Country. New York in London: Harper \& Brothers.

AnIĆ, Ante 1919 Govori D.ra Ante Tresić-Pavičića izrečeni u austrijskom parlamentu za vrijeme rata. Dubrovnik: Izdanje Knjižare J. Tošović.

AshPlant, T. G. 2000 War commemoration in Western Europe: changing meanings, divisive loyalties, unheard voices; T. G. Ashplant, Graham Dawson in Michael Roper, ur. The Politics of War Memory and Commemoration, str. 263-272. London: Routledge.

Ashplant, T. G., Graham Dawson i Michael Roper, ur. 2000 The Politics of War Menmory and Commemoration. London: Routledge.

BÁle , Jaroslav 2018100 let proher a vitěžství. O politice a smyslu českých dëjin. Praha: Martin Koláček.

Banjanin, Jovan 1915 Južni Sloveni u Austro-Ugarskoj i rat; Savremena pitanja, št. 6, str. $14-24$.

BARTUlović, Niko 1925 Od Revolucionarne Omladine do Orjune. Istorijat jugoslovenskog omladinskog pokreta. Split: Izdanja Direktoriuma Orjune. 
BLAŠKoviĆ, PERO 1939 Sa Bošnjacima u Svjetskom ratu. Beograd: Štampa „Globus“.

BоваN, LJubo 1989 Kontroverze iz povijesti Jugoslavije. Dokumentima i polemikom o temama iz novije povijesti Jugoslavije. Zagreb: Školska knjiga, Stvarnost.

Bobič, Pavlina 2012 War and Faith. The Catholic Church in Slovenia, 1914-1918. Leiden in Boston: Brill.

Bokovoy, Melissa 2001 Scattered Graves, Ordered Cemeteries. Commemorating Serbia's Wars of National Liberation, 1912-1918; Maria Bucur in Nancy M. Wingfield, ur. Staging the Past. The Politics of Commemoration in Habsburg Central Europe, 1848 to the Present, str. 236-254. West Lafayette: Purdue University Press.

Bonač, Fran $1924 \mathrm{Ob}$ odkritju spominske plošče Selčanom; Slovenec, 17. maja, str. 2-3.

1929 Trije glasovi ...; Mladika, št. 11, str. 407-408.

1931 Spomin umrlim; Bojevnik, 15. avgusta, str. 1-2.

1932. Spominsko pokopališče bojevnikov na pokopališču pri Sv. Križu; Bojevnik, 25. junija, str. 2-3.

Borg, AlAn 1991 War Memorials from Antiquity to the Present. London: Leo Cooper.

Breitenberger, IgnaCiJ 1914 †ranc Ferdinand; Mladost, št. 7, str. 89-91.

BrüCKner, Alexander 1916 Die Slawen und der Weltkrieg. Tübingen: Verlag von J. C. B. Mohr (Paul Siebeck).

BUCHAN, JoHn 1923 Yugoslavia. London: Hodder and Stoughton.

Conrad, Feldmarschall 1921 Aus meiner Dienstzeit 1906-1918. Erster Band: Die Zeit der Annexionskrise 1906-1909. Wien: Rikola Verlag.

Cornwall, Mark 2000 The Undermining of Austria-Hungary. The Battle for Hearts and Minds. Basingstoke: Macmillan Press.

ČASTNI ODBOR 1937 Vsem Slovencem!; Gorenjec, 15. maja, str. 1.

ČopIČ, ŠPELCA 1987 Slovenski spomeniki padlim v prvi svetovni vojni; Kronika, št. 3, str. $168-177$.

Ćorović, Vladimir 1936 Odnosi izmedu Srbije i Austro-Ugarske u XX veku. Beograd: Štampa Državne štamparije Kraljevine Jugoslavije.

Dimić, Ljubodrag 1998 Srbi i Jugoslavija. Prostor, društvo, politika. (Pogled s kraja veka). Beograd: Stubovi kulture.

Dobida, KAREL 1929 Naši vojaški spomeniki; Mladika, št. 11, str. 430-431.

Domolju в 1914 Ferdinandovo varstvo; Svetovna Vojska, št. 1, str. 3-4.

Dragnich, Alex N. 1983 The First Yugoslavia. Search for a Viable Political System. Stanford: Hoover Institution Press.

ERJAVEC, FrAN 1928 Zgodovina katoliškega gibanja na Slovenskem. Ljubljana: Izdala in založila Prosvetna zveza. 
F. B. (FrANCÈ BoNAČ) 1923 Naša sramota; Slovenec, 24. oktobra, str. 3.

F. G. 1924 1914-1924.; Slovenec, 25. julija, str. 1.

FLeRÈ, PAVEl 1916 Avstrijska slava v prvih dneh svetovne vojne. Dunaj: C. kr. založba šolskih knjig na Dunaju.

Fraser, Mike 2014 The Lamps Went Out. Sir Edward Grey and "the War to End all Wars". Berwick upon Tweed: Blue Button Publications.

G. P. 1915 Bojišče - rojstni kraj svetnikov; Glasnik najsvetejših Src, št. 6, str. 88-90.

Gerolymatos, ANdré 2002. The Balkan Wars. New York: Basic Books.

Gillis, John R., UR. 1994 Commemorations. The Politics of National Identity. Princeton: Princeton University Press.

GLAVNI ODвоR Z.S.V. 1925 Odgovor Zveze slovenskih vojakov »Politiki« in drugim; Slovenec, 15 . novembra, str. 2.

Glavni odbor Zveze SLOVEnSkih vojakov 1927 Vojni tovariši!; Slovenski Gospodar, 10. novembra, str. 3 .

GoveKar, Fran 1922 Če bi nas bil vzel hudič...; Slovenski Narod, 28. junija, str. 1.

HAFNER, JERNEJ 1914 Slovenskim fantom za slovo na pot $v$ cesarsko službo. Ljubljana: Založila Katoliška Bukvarna.

Hajšman, JAN 1932 Česká mafie. Vzpominki na odboj doma. Praha: Sfinx Bohumil Janda.

HerCeg, Rudolf 1919 Svjetski Rat i problem nove države. Zagreb: Naklada piščeva.

Holeček, Marijofil 1915 Premišljevanja o božjem Srcu Jezusovem. Ljubljana. Samozaložba.

HoRvat, Josip 1967 Prvi svjetski rat. Panorama zbivanja 1914-1918. Zagreb: Novinarska izdavačka kuća Stvarnost.

Hribar, Alfons 1929 Jugoslavenska Politika (Srba, Hrvata, Slovenaca i Bugara). Zagreb: Agrarna biblioteka.

HRIBAR, IVAN 1928 Moji spomini. Ljubljana: Natisnila Tiskarna Merkur.

J. H. 1923 Skrb za vojaške grobove; Slovenec, 27. oktobra, str. 2.

JAKovljeVIĆ, MARKo 1923 Iz rata i emigracije (uspomene). Odgovor g. Jovanu Tomiću. Subotica: Štamparija Etelke Rajčić.

JANKović, Dragoslav 1983 Oko unitarnog i federativnog uređenja prve zajedničke jugoslovenske države; Nikola B. Popović, ur. 1983. Stvaranje jugoslovenske države 1918. Zbornik radova podnetih na naučnom skupu u Iloku od 16. do 19. maja 1979, str. 383-392. Beograd: Institut za savremenu istoriju i »Narodna knjiga $\ll$.

Jeglič, Anton Bonaventura 1914a Dnevnik; rokopis c Nadškofijskem arhivu Ljubljana, fond Škofijski arhiv Ljubljana, dnevnik škofa Jegliča, škatla 13/1c.

1914b Besede ljubljanskega knezoškofa; Slovenec, 11. avgusta, str. 1. 
JEVtIĆ, BorIVoJe 1923 Sarajevski atentat. Sećanja i utisci. Sarajevo: Štampa i izdanje Petra N. Gakovića.

JojKIć, Milan 1918 U susret srpskoj vojsci. Doživljaji od tri dana. Sarajevo: Izdanje I. Gj. Gjurgjevića.

JURIŠIĆ, PAVle 1924 Kroz našu nacionalnu krizu. Beograd: Štamparija „Jadran“.

K. M. H. 1935 Zakaj postavljamo spomenike?; Gorenjec, 20. aprila, str. 1.

Klemenčič, IVANKA 1914 Zločin v Sarajevu. Tragična smrt prestolonaslednika Fran Ferdinanda in njegove soproge vojvodinje Hohenberg. Ljubljana: Katoliška Bukvarna.

Kolar, Ivan Janez 1930 Preporodovci 1912-1914. Kamnik: Založila Tiskarna Anton Slatnar.

Kosi, Anton 1914 Izpod črno-rumene zastave. Zanimivi dogodki in slike iz vojnega viharja v Avstriji l. 1914. Maribor: V založbi izdajateljevi.

KRANJČEVIĆ, IVAN 1954 Uspomene jednog učesnika u sarajevskom atentatu. Sarajevo: Svjetlost.

KrUleJ, ERnest 1936 Vse za Jugoslavijo; Ernest Turk, Josip Jeras i Rajko Paulin, ur. Dobrovoljci kladivarji Jugoslavije 1912-1918, str. 178-218. Ljubljana: Izdanje in samozaložba „Sreskih organizacij Saveza ratnih dobrovoljaca Kraljevine Jugoslavije“ v Ljubljani in Mariboru.

LAH, Ivan 1925 Knjiga spominov. Ječe - moja pot - Dan 1914. Ljubljana: Založila Tiskovna zadruga.

LILEK, EM 1927 Konstantierung über der Schuld am Ausbruche des Weltkrieges 1914. Celje: Selbstverlag.

LIMBARSKI 1914 Vojak pred tabernakljem; Glasnik najsvetejših Src, št. 11, str. 181.

LJ 1917 Koliko vojakov leži pokopanih pri Sv. Križu; Slovenec, 3. novembra, str. 4.

LONČAR, Dragotin 1921 Politično življenje Slovencev. (Od 4. januarja 1797. do 6.januarja 1919. leta). Ljubljana: Slovenska matica.

LONČAREVIĆ, DušAN A. 1919 Domaća štampa. Beograd: Izdanje S. B. Cvijanovića.

1929 Jugoslaviens Entstehung. Zürich, Leipzig, Wien: Amalthea-Verlag.

Ludwig, ERnest 1915 Austria-Hungary and the War. New York: J. S. Ogilvie Publishing Company.

M. K. $1915 \gg$ Kranjski Janez«; Tedenske slike, 3. marca, str. 2.

MAL, Josip 1928 Zgodovina slovenskega naroda. Novejša doba. Celje: Družba sv. Mohorja.

Manojlović Pintar, Olga 2014 Arheologija sećanja. Spomenici i identiteti u Srbiji 1918-1989. Beograd: Čigoja štampa.

Matičıč, IVAN $1922 \mathrm{Na}$ krvavih poljanah. Trpljenje in strahote z bojnih pohodov bivšega slovenskega planinskega polka. Ljubljana: Natisnila in založila Učiteljska tiskarna. 
Moriarty, Catherine 1997 Private Grief and Public Remembrance: British First World War Memorials; Martin Evans in Kenneth Lunn, ur. 1997. War and Memory in the Twentieth Century, str. 125-142. Oxford: Berg.

Mosse, George L. 1975 The Nationalization of the Masses. Political Symbolism and the Mass Movements in Germany from the Napoleonic Wars Through the Third Reich. New York: Howard Fertig.

1990 Fallen Soldiers. Reshaping the Memory of the World Wars. New York in Oxford: Oxford University Press.

1914a Atentat u Austriji; Pravda, 17. junija, str. 1-

1914b V tretje gre rado; Svetovna vojska, zv. 1. str. 17-19.

1914c Naš sovražnik; Slovenec, 1. julija, str. 1.

1914d Pod staro slovensko zastavo; Slovenec, 6. julija, str. 1-4.

1914e Südslawische Demonstration im - Leichenzug des Thronfolgers; Marburger Zeitung, 4. julija, str. 6.

1914f Pomenljiva dejstva; Dan, 8. julija, str. 1

1914g Bojni grom; Slovenec, 27. julija, str. 1.

1914h Živela Avstrija! Doli s Srbijo!; Slovenec, 27. julija, str. 1.

1914i Slovenski fantje gredo navdušeno na vojsko; Slovenski Gospodar, 28. julija, str. 1 .

1914j Ljubljana manifestira; Slovenec, 29. julija, str. 1-2.

1914k Ob zgodovinski uri; Slovenec, 29. julija, str. 1-2.

19141 Vojska; Slovenec, 29. julija, str. 1.

1914m Ljudska duša; Slovenec, 30. julija, str. 1.

1914n Odšli so v pravično vojsko; Novi Čas, 30. julija, str. 1.

1914lo Prvi strel; Svetovna Vojska, zv. 1, str. 2-3.

1914 p Vojska protiv nas; Politika, 1. avgusta, str. 1.

1914q En Hrvat za tri Srbe; Slovenec, 27. avgusta, str. 1.

1914r Slovenski fantje v bojih s Srbi; Tedenske Slike, 2. septembra, str. 3-6.

$1914 \mathrm{~s}$ V večen spomin padlih vojakov; Slovenec, 18. septembra, str. 3.

1914t Častniki 17. pešpolka; Ilustrirani Glasnik, 24. septembra, str. 42-43.

1914u Slovenski vojaki - vedno junaki!; Slovenec, 14. novembra, str. 1.

1915a Katoliški Slovenci!; Dolenjske Novice, 6. avgusta, str. 1.

1915b Katoliški Slovenci!; Slovenec, 10. avgusta, str. 1. 
1915c Zakaj še na Brezje?; Domoljub, 12. avgusta, str. 461-462.

1915d K cesarjevi petinosemdesetletnici; Slovenski Narod, 17. avgusta, str. 1

1915e Cesarju in armadi; Slovenski Narod, 17. avgusta, str. 2.

1915f Romanje na Brezje; Slovenski Gospodar, 19. avgusta, str. 4.

1915g Naše ljudstvo praznuje cesarjev rojstni dan pri »Mariji Pomagaj «; Domoljub, 19. avgusta, str. 484.

1916a Iz Judenburga, 28. januarja; Slovenec, 1. februarja, str. 4.

1916b Zgodovinski spomenik 17. pešpolka v Ljubljani; Slovenec, 11. marca, str. 5.

$1916 \mathrm{c}$ Vojna z Lahi. General pl. Boroević - častni ljubljanski meščan; Tedenske slike, 18. avgusta, str. 5-6.

1917 Ljubljanski občinski svet, Slovenec, 4. aprila, str. 1-2.

1918 Slovenski vojaki!; Slovenski gospodar, 7. novembra, str. 2

1919 Ljubljanski občinski svet; Slovenski narod, 25. junija, str. 3.

1920 Vidov dar; Slovenski Narod, 27. junija, str. 6.

1923a Nagrobnik judenburškim žrtvam; Mladika, št. 7, str. 277.

1923b Maršal Boroević o vojni proti Italiji; Slovenski narod, 15. novembra, str. 1.

1924 Prazniki; Slovenec, 1 . novembra, str. 1.

1925a Dovje-Mojstrana; Jutro, 20. maja, str. 7.

1925b Slovesno odkritje spomenika padlim vojakom občine Dovje-Mojstrana; Slovenski Narod, 20. maja, str. 3.

1925c Spomenik padlim vojakom občine Dovje-Mojstrana; Jutro, 21. maja, s. 4.

1925 Veličasten zbor slovenskih vojakov na Brezjah; Novi Domoljub, 10. septembra, str. 377 .

1926 Občni zbor Z. S. V. na Brezjah; Slovenec, 10. avgusta, str. 6.

1927 45. pešpolk svojim mrtvim tovarišem; Slovenec, 24. junija, str. 3.

1928a Spomenik vojnim žrtvam v Škofji Loki; Slovenski Narod, 20. septembra, str. 2.

1928b Veličasten spomenik vojnim žrtvam; Domovina, 27. septembra, str. 9

1928c Spomenik zaslužnim za domovino; Jutro, 13. oktobra, str. 3.

1933a Mogočen tabor JRKD pri Sv. Jakobu; Jutro, 17. julija, str. 1.

1933b Naša pravica; Bojevnik, 4. novembra, str. 1. 
1933c Dragi tovariši!; Bojevnik, 4. novembra, str. 3.

1933d Padlim junakom trebanjske fare; Jutro, 26. novembra, str. 3.

1933e Odkritje spomenika trebanjskim padlim vojakom Trebnje; Jutro, 27. novembra, str. 2.

$1933 f$ Trebnje spominu vojnih žrtev; Slovenec, 27. novembra, s. 1.

1933g Trebnje spominu padlih vojakov; Slovenski Narod, 27. novembra, str. 2.

1933h V spomin trebanjskim vojnim žrtvam; Slovenec, 28. novembra, str. 3. 1933i Spomenik trebanjskim vojnim žrtvam (Trebnje); Domoljub, 29. novembra, str. 610 .

1933j Odkritje spomenika trebanjskim padlim vojakom; Domovina, 30. novembra, str. 7.

1934a Slovenci in Jugoslovani smo!; Bojevnik, 15. aprila, str. 1.

1934b Moste pri Ljubljani; Bojevnik, 15. aprila, str. 2-3.

1934c Maribor; Bojevnik, 15. aprila, str. 3-4.

1934d Tako se ne dela ne za narod, ne za državo; Domovina, 17. maja, str. $1-2$.

1934e Mimogrede; Jutro, 7. junija, str. 4.

1934 f Važna zadeva; Domoljub, 13. junija, str. 1.

1935a Vodice; Gorenjec, 9. marca, str. 3.

1935b Komendsko slavje; Gorenjec, 18. avgusta, str. 1-2.

1935c Judenburg v spomin slovenskih fantov in mož; Ponedeljski Slovenec, 11. novembra, str. 1 .

1935d Bojevniki!; Gorenjec, 2. novembra, str. 2.

1935e Za zedinjeno Slovenijo; Bojevnik, 8. decembra, str. 1.

1936 Vodja nekdanjih »bojevnikov《 Stane Vidmar obsojen; Nova Doba, 21. februarja, str. 1 .

1937a Proč z mostninarji; Gorenjec, 18. septembra, str. 1-2.

1937b Tabor; Slovenski Gospodar, 18. avgusta, str. 6-7.

1937c Tabor bojevnikov na Brinjevi gori; Slovenski Gospodar, 18. avgusta, str. 11.

1937d Blagoslovitev temeljnega kamna; Slovenec, 30. avgusta, str. 1.

1937e Zborovanje bojevnikov; Slovenec, 30. avgusta, str. 1 .

1937f Slovenski bojevniki pri Mariji Pomagaj; Slovenec, 30. avgusta, str. 1 . 
1937g Po velikih bojevniških slavnostih na Brezjah; Slovenec, 5. septembra, str. 6.

1938a Za skupen spomenik vojnim žrtvam; Slovenski Gospodar, 9. marca, str. 1.

1938 b Imena v svetovni vojni padlih in umrlih ob grobu neznanega slovenskega vojaka na Brezjah; Slovenski Gospodar, 20. april, str. 8.

1938c Mrtvi Vas pozdravljajo; Gorenjec, 23. aprila, str. 1.

1938d Spomin padlim v svetovni vojni; Kranjski Zvon, št. 6, str. 25-26.

1938f Spomenik padlim vojakom; Slovenec, 28. septembra, str. 8.

$1938 \mathrm{~g}$ Nočni napad na spomenik v vojni padlim; Slovenec, 29. septembra, str. 3.

1939a Za spomenik slovenskim žrtvam svetovne vojne; Gorenjec, 4. marca, str. 2.

1939b 1914-1939; Slovenec, 3. avgusta, str. 1.

1940a Praznik Zveze bojevnikov; Slovenski Gospodar, 21. avgust, str. 6-7.

1940b »Zveza bojevnikov«; Slovenski Gospodar, 30. oktober, str. 13.

Newman, John Paul 2011 Forging a United Kingdom of Serbs, Croats, and Slovenes. The legacy of the First World War and the 'invalid question'; Dejan Djokić in James Ker-Lindsay, ur. New Perspectives on Yugoslavia. Key Issues and Controversies, str. 46-61. London in New York: Routledge.

2015 Yugoslavia in the Shadow of War. Veterans and the Limits of State Building, 1903-1945. Cambridge: Cambridge University Press.

NeZnan, Ivica 1919 Ali spada ženska v politiko?; Slovenka, 15. junija, str. 91-94.

Oblak, Josip Cir. 1920 Narodni heroizem in mi; Slovenski Narod, 21. novembra, str. 1.

ObRAdović, DušAN N. 1928 Srbija i austrijski Sloveni u Svetskom ratu 1914-1918. Novi Sad: Zastava.

ODBOR ZA PRENOS KOSTI IVANA ENDLICHERJA IN ODBOR ZA PRENOS KOSTI JUDENBURŠKIH ŽRTEV 1923 Svobodnemu narodu!; Slovenski Narod, 31. maja, str. 1.

OreŠAN 1917. Slovenski umetnik (Svetko Peruzzi); Zvonček, 1. maja, str. 113-116.

Orzoff, ANDREA 2004 The Empire without Qualities: Austro-Hungarian Newspapers and the Outbreak of War in 1914; Troy R. E. Paddock, ur. A Call to Arms. Propaganda, Public Opinion, and Newspapers in the Great War, str. 161-198. Westport: Praeger.

OSREDNJI ODBOR ZvEZE BoJEVNIKov 1933 »Zlorabljanje Zveze bojevnikov《; Slove$n e c, 16$. julija, str. 3 .

PALIR, JAков 1914 Sv. maša z otirom na bojni grom; Glasnik najsvetejših Src, št. 9, str. 149-150.

Paulin, Rajko 1936 † Jenko Avgust - Kladivar besede in dejanja; Ernest Turk, Josip Jeras i Rajko Paulin, ur. Dobrovoljci kladivarji Jugoslavije 1912-1918, str. 131-137. Ljubljana: Izdanje in samozaložba „Sreskih organizacij Saveza ratnih dobrovoljaca Kraljevine Jugoslavije“ v Ljubljani in Mariboru. 
Paulová, Milada 1924Jugoslavenski Odbor. (Povijest jugoslovenske emigracije za Svjetskog rata od 1914.-1918.). Zagreb: Prosvjetna nakladna zadruga.

Pavlowitch, Kosta St. 2003 The First World War and the Unification of Yugoslavia; Dejan Djokić, ur. 2003. Yugoslavism. Histories of a Failed Idea 1918-1992, str. 27-41. London: Hurst \& Company.

PeČovski 1914 Vse za vero, dom, cesarja!; Glasnik najsveteših Src, št. 8, str. 130-136.

1915. Sv. Florijan vojni patron; Glasnik najsveteših Src, št. 6, str. 93-94.

Peerz, Rudolf 1916a Našim vojakom. V Gradcu: Tiskarna Kornega poveljstva.

$1916 \mathrm{~b}$ In zopet kliče domovina! Beseda vsem, ki so zvesti domovini. Na Dunaju: Iz c. kr. dvorne in državne tiskarne.

1917 Vse za vojskujočo se domovina! Doživljaji vojnega popotnika v zaledju. Resnični dogodki. Na Dunaju: Iz c. kr. dvorne in državne tiskarne.

Petranović, Branko 1980 Istorija Jugoslavije 1918-1978. Beograd: Nolit.

Pleterski, Janko 1971 Prva odločitev Slovencev za Jugoslavijo. Politika na domačih tleh med vojno 1914-1918. Ljubljana: Slovenska matica.

PoInCARÉ, RAYMond 1921 Les origines de la guerre. Paris: Librairie Plon.

РотоČNJAK, Franko 1915 Jugoslovensko pitanje u velikom istorijskome času. New York: Tisak tiskare „Hrvatskoga Svijeta“.

Protić, Stojan 2006 Kralj je bio na suprotnoj strani. Zapisi iz naše političke istorije. Beograd: Čigoja štampa.

2009 Jugoslavija protiv Srbije. Zapisi iz naše političke istorije. Beograd: Čigoja štampa.

Purivatra, Atif 1974 Jugoslavenska muslimanska organizacija u političkom životu Kraljevine Srba, Hrvata i Slovenaca. Sarajevo: Svjetlost.

RENAN, ERNEST 1882 Qu-est-ce qu'une nation? Conférence faite en Sorbonne, le 11 Mars 1882. Paris: Calman Lévy.

Ristanović, Slobodan 1989 Cerska bitka. Loznica: Muzej Jadra.

Romsics, Gergely 2006 Myth and Remembrance. The Dissolution of the Habsburg Empire in the Memoir Literature of the Austro-Hungarian Political Elite. Wayne: Center for Hungarian Studies and Publications.

Roshwald, Aviel 2001 Ethnic Nationalism and the Fall of Empires. Central Europe, Russia and the Middle East, 1914-1923. London: Routledge.

SimČIČ, Miro 2014 Preden listje odpade, bomo doma. Slovenci v prvi svetovni vojni (1914-1918). Ljubljana: Buča.

Singleton, Fred 1985 A Short History of the Yugoslav Peoples. Cambridge: Cambridge University Press.

SPINDLER, VeKoSLAV 1934 Tožitelji in rešitelji; Jutro, 15. junija, str. 2.

STELÈ, FranCE 1931 Vojni spomenik v Breznici; Mladika, str. 409-414. 
Strobl, KARL HANS 1915 V Italijanskem granatnem ognju; Slovenec, 27. avgusta, str. 1-2.

Supilo, Franjo 1970 Politički spisi. Članci, govori, pisma, memorandumi. Zagreb: Znanje.

ŠEgula, FRANČiŠEK SERAFIn 1917 Križev pot za vojni čas. Maribor: Tisk in založba Tiskarne sv. Cirila.

ŠIŠIĆ, FERDO 1937 Jugoslovenska misao. Istorija ideje jugoslovenskog narodnog ujedinjenja i oslobodenja od 1790-1918. Beograd: Izdanje Balkanskog instituta.

ŠUŠTERŠIČ, IVAN 1922 Moj odgovor. Samozaložba.

TARTAglia, OsKar 1928 Veleizdajnik (moje uspomene iz borbe protiv crno-žutog orla). Zagreb: Tiskara i litografija C. Albrecht (D. Šrepelj).

Troch, Pieter 2015 Nationalism and Yugoslavia. Education, Yugoslavismand the Balkans Before World War II. London: I. B. Tauris.

Van Ypersele, Laurence 2010 Mourning and Memory, 1919-45; John Horne, ur. A Companion to World War I, str. 576-590. Malden, MA, Oxford: Wiley-Blackwell.

Vertin, JANKo 1933 Obisk vojnih grobov ob Soči; Bojevnik, 1. julija, str. 5.

VošnJa K, Bogumil 1938 Tri Jugoslavije. Jugoslavija v emigraciji; Misel in delo, št. 12, str. 45-55.

Vukićević, Milenko M. 1924 Petrograd u početku Velikoga rata 1914. godine; ; Krv Slovenstva 1914-1924. Spomenica desetogodišnjice Svetskog rata, str. 101-111. Beograd: Štamparija Save Radenkovića i brata.

Watson, Alexander 2014 Ring of Steel. Germany and Austria-Hungary at War, 19141918. London: Allen Lane.

Wendel, Hermann 1925 Der Kampf der Südslawen um Freiheit und Einheit. Frankfurt am Main: Frankfurter-Sociatäts.

West, Rebecca 1942 Black Lamb and Grey Falcon. The Record of a Journey through Yugoslavia in 1937. London: Macmillan \& Co.

Winter, Jay 2006 Remembering War. The Great War Between Memory and History in the Twentieth Century. New Haven in London: Yale University Press.

Z. $1925 \gg$ Palim Vojakom «; Politika, 4. novembra, str. 5.

Ziemann, Benjamin 2013 Contested Commemorations. Republican War Veterans and Weimar Political Culture. Cambridge: Cambridge University Press. 